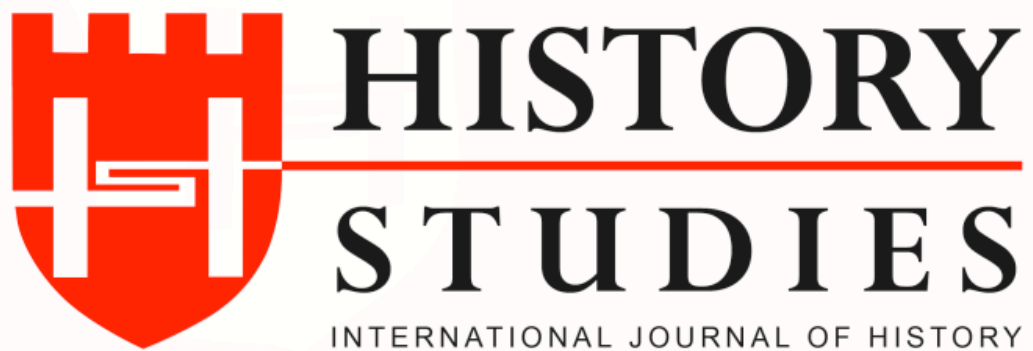

ISSN: 13094173 (Online) 1309 - 4688 (Print)

Volume 11 Issue 3, June 2019

DOI Number: 10.9737/hist.2019.747

Araştırma Makalesi

Makalenin Geliş Tarihi: 11.04.2019 Kabul Tarihi: 28.05.2019

Atıf Künyesi: Mehmet Gündüz, "İspanyol Basınına Göre II. Abdülhamid ve Bu Dönemde Yaşanan Siyasi Gelișmeler”, History Studies, 11/3, Haziran 2019, s. 915-941.

\title{
İspanyol Basınına Göre II. Abdülhamid ve Bu Dönemde Yaşanan Siyasi Gelişmeler
}

\author{
According To The Spanish Press Abdulhamid II And Political Developments In This \\ Period
}

Dr. Mehmet Gündüz

ORCID No: 0000-0002-4642-4189

İstanbul Erkek Lisesi

\begin{abstract}
Öz: II. Abdülhamid Osmanlı Devleti'nin zor günler yaşadığı bir dönemde tahta çıkmıştır. Hükümdarlığının ilk yıllarında Abdülhamid büyük yıkımlara yol açan 1877-1878 OsmanlıRus Savaşı'yla uğraşmıştır. Bu savaştan sonra Osmanlı Devleti, II. Abdülhamid'in izlediği denge politikası sayesinde uzun bir barış dönemine girmiştir. Sultan Abdülhamid izlediği akılcı politikalar sayesinde Osmanlı Devleti'nin büyük devlet olma vasfını korumaya çalışmıştır. 1897'de Yunanlılarla yaşanan Dömeke Meydan Muharebesi Osmanlı Devleti'nin galibiyetiyle sonuçlanmıştır. Buna rağmen Osmanlı Devleti'nin Rumeli'de yaşadığı so runlar giderek artmıştır. 1908'de İngiltere ve Rusya arasında yapılan Reval Görüşmelerinden sonra Osmanlı Devleti'nde muhalefet II. Abdülhamid üzerindeki baskıyı artırmıştır. Bu baskı sonrasında Meşrutiyeti yeniden ilan etmek zorunda kalan II. Abdülhamid, 31 Mart Vak'ası sonra tahtan indirilmişsir. Tahtan indirildikten sonra Selanik ve İstanbul'da sürgün hayatı yaşamak zorunda kalan II Abdülhamid 10 Şubat 1918'de vefat etmiştir. Bu çalışma kapsamında 1876-1918 yılları arasında İspanyol basınında II. Abdülhamid ve Osmanlı Devleti'yle ilgili çıkmış haberler incelenmiştir ve İspanyol gazetelerinin gözünden II. Abdülhamid ve dönemine ilişkin genel bir perspektif çizilmiştir.
\end{abstract}

Anahtar Kelimeler: İspanyol Basını, II. Abdülhamid, Osmanlı Devleti, Türkiye, Meşrutiyet.

Abstract: Abdulhamid II ascended the throne at a time when it is difficult days of the Ottoman Empire. In the early years of his reign Abdulhamid was engaged in the 1877-1878 Ottoman-Russian War, which led to great destruction. Thanks to the balance policy of Abdülhamid II, the Ottoman Empire entered a long period of peace after this war. Sultan Abdülhamid tried to preserve the characteristic of the Ottoman Empire as a great state with his rational policies followed. In 1897, the Battle of Dömeke with the Greeks resulted in the victory of the Ottoman Empire. Nevertheless, the problems of the Ottoman Empire in Rumelia have increased. After the Reval talks between England and Russia in 1908, the opposition in the Ottoman Empire increased the pressure on Abdülhamid II. Abdülhamid II, who had to re-declare the Constitutional Monarchy after this pressure, was freed after the 
March 31st Case. Abdulhamid II, who was forced to live exile in Salonica and Istanbul after his abdication, died on 10 February 1918. In this study, between 1876-1918 in the Spanish press, the news related to Abdülhamid II and Ottoman Empire were examined. Furthermore, a general perspective of Abdulhamid II and his period was drawn from the eyes of Spanish newspapers.

Keywords: Spanish Press, Abdulhamid II, the Ottoman Empire, Turkey, Constitutional.

\section{Giriş}

XIX. yüzyıl Osmanlı Devleti için birçok önemli gelişmenin yaşandığı ve ülkenin varlığının korunmaya çalışıldığı bir dönem olmuştur. Osmanlı Devleti'nin savaş meydanlarındaki yenilgileri ve toprak kayıpları başta askeri olmak üzere birçok alanda 1slahat çalışmalarına ve bu çalışmalarda beraberinde yeni tartışmalara zemin hazırlamıştır. Osmanlı Devleti, Paris kongresinden sonra birçok gaile ile uğraşırken Sultan Abdülmecid 25 Haziran 1861'de ölmüş ve yerine kardeşi Abdülaziz Padişah olmuştur. ${ }^{1}$ Sultan Abdülaziz döneminde Osmanlı Devleti, Hersek İsyanı, Selanik Olayı, Bulgar İsyanları, Lübnan'daki çatışmalar, Karadağ'daki isyan hareketleri, Girit meselesi, Berlin Memorandumu gibi birçok olay ve gelişme uğraşmak zorunda kalmıştır. ${ }^{2}$ 1870'lerden sonra koşullar Osmanlı Devleti için hızla değişmeye başlamıştır. Büyük masraflara yol açmış olan ordu ve donanmadaki yenilemeler, padişahın israfı ve nazırların harcamaları devlet hazinesini altüst etmiştir. 1875 'te Sadrazam Mahmud Nedim Paşa'nın Rus elçisi İgnatiyef' in tavsiyelerine uyarak Osmanlı borçlarının faizlerini yarıya indirme kararı Avrupa devletlerinin şiddetli tepkisiyle karşılaşmıştır. ${ }^{3}$

Halk arasında Sultan Abdülaziz'e yönelik tepkilerin arttığı ve İstanbul'da Müslüman ile Hristiyan ahalinin birbirlerine saldıracakları yönünde Rus elçisi İgnatiyef'in körüklediği söylentilerin çıktığı bir ortamda Sadrazam Nedim Paşa ve Şeyhülislam Fehmi Efendi'nin Rus taraftarlığı haklı endişelendirmiştir. ${ }^{4}$ Taşradaki karışıklıkların yanında Temmuz 1875 'te Balkanlarda çıkan ayaklanmalar Osmanlı Devleti ile Avrupalı devletlerinin arasını daha da açtı ve bu durum İstanbul'da Padişaha karşı giderek büyüyen bir tepkiye yol açmıştır. ${ }^{5}$ Ayrıca "devlet adamları arasındaki mücadele de günden güne artmaktaydı. Midhat ve Hüseyin Avni Paşalar Abdülaziz'i hem devlet için, hem de kendileri için zararlı gördüklerinden düşmanca bir tavır içinde idiler" ve İstanbul medreselerindeki talebeleri de el altından kışkırtıyorlardı. ${ }^{6}$ Sultan Abdülaziz'in saltanatının son yıllarında iç ve dış hadiselerin çokluğu ile yaşanan buhranlar dolayısıyla oluşan hoşnutsuzluğu Hüseyin Avni Paşa iyi değerlendirmiş ve bu durumu Sultan Abdülaziz'i tahtan indirmek için kullanmıştır. ${ }^{7}$ Nitekim medrese öğrencileri ülkenin içinde bulunduğu duruma çare bulmak amaciyla İstanbul'da mitingler düzenlemiş, Sadrazam Nedim Paşa ve Şeyhülislam Fehmi Efendi'nin azillerini istemiştir. II. Abdülhamid, Sultan Abdülaziz'in bu nümâyişlere ve fesat hareketlerine şiddetle karşıllk vermesi gerektiği halde ürktüğü için sert cevap vermediğini belirtmiştir. II. Abdülhamid bu hareketleri Rüşdi, Midhat, Damat Mahmud ve Halim Paşalarla, perde arkasından Veliahd Murad Efendi'nin tertip ettiklerini ve neticede de muvaffak olarak Rüsşi, Avni, Midhat Paşalarla Hayrullah Efendi'nin iş başına geldiğini söylemiştir. ${ }^{8} \mathrm{Bu}$ değişiklilerin olduğu bir ortamda Berlin'de Alman,

\footnotetext{
${ }^{1}$ Fahir Armaoğlu, 19. Yüzyıl Siyasi Tarihi, TTK Yayınları, Ankara 1999, s.270.

${ }^{2}$ Age, s.503.

${ }^{3}$ Bernard Lewis, Modern Türkiye'nin Doğuşu, TTK Yayınları, Ankara 2000, s.158.

${ }^{4}$ Haluk Y. Şehsuvaroğlu, Sultan Aziz, TBMM Milli Saraylar Yayını, İstanbul 2011, s.74-75

${ }^{5}$ Lewis, age, s. 158 .

${ }^{6}$ Cevdet Küçük, “Abdülaziz”, DİA, İstanbul 1988, C.I, s.183.

${ }^{7}$ Zuhuri Danışman, Osmanlı İmparatorluğu Tarihi, Zuhuri Danışman Yayınevi, İstanbul 1966, C.XII, s.258.

${ }^{8}$ Şehsuvaroğlu, age, s.77-78.
} 
Avusturya ve Rus İmparatorluğu Osmanlı Devleti’nin geleceğiyle ilgili gizli görüşmeler yapıyordu. Ayrıca Bulgarlar Rusların tahrikiyle isyan etmişlerdi. "Halkın memnuniyetsizliği ve vükelânın, memleketin âtisinden endişeye düşmeleri, Abdülaziz aleyhinde umûmî efkârı hazırlamış ve Padişahın hal'inden başka bir çare görülmez olmuştur." "9 Nihayetinde 30 Mayıs 1876'da Mithat Paşa, Hüseyin Avni Paşa ve Süleyman Paşa'nın başını çektiği bir grubun girişimi sonucunda Sultan Abdülaziz tahtan indirilmiş ve yerine masonların desteklediği ve kendisi de bir mason olan Şehzade Murad, V. Murad adıyla tahta çıkmıştır. ${ }^{10}$

V. Murad'ın tahta çıkması hürriyetçiler için bir zafer gibi gözükse de hürriyetçilerin yeni hükümdardan memnuniyetleri kısa sürmüştür. Şehzadeliği döneminde yaşadığı fiili göz hapsinin sebep olduğu gerginlikler V. Murad'da padişah olduğunda artık iyice akli bozukluk yolunda ilerlemiştir. Ayrıca Sultan Abdülaziz'in feci ölümü ve Çerkes Hasan'ın Sultan Abdülaziz'in ölümünden sorumlu tuttuğu Hüseyin Avni Paşa ile diğer nazırları kabine toplantısını basarak öldürmesi padişahın ruh sağlığını daha da kötüleştirmiştir. İç ve dış buhranların giderek arttığı bir ortamda bu durum göz yumulamaz hale gelmiş ve devlet adamları istemeyerek de olsa ikinci bir saltanat değişimi ihtimalini düşünmeye başlamışlardır. ${ }^{11}$ Nitekim Bakanlar Kurulu ve Midhat Paşa, V. Murad'ı tahtan indirmeye ve yerine Şehzade Abdülhamid'i tahta çıkarmaya karar vermişlerdir. ${ }^{12}$ Anayasaya dayalı meşruti bir idare kurmak isteyen ve bu yüzden Abdülaziz ile V. Murad'ı tahttan indiren Midhat Paşa ve arkadaşlarıyla anlaşan Şehzade Abdülhamid 31 Ağustos 1876 'da II. Abdülhamid adıyla tahta çıkmıştır. ${ }^{13}$

II. Abdülhamid ve dönemiyle ilgili birçok yayın ve çalışma yapılmış olmasına rağmen İspanyol basınında II. Abdülhamid ve döneminin nasıl yansıdığıyla ilgili çok az çalışma bulunmaktadır. Fakat İspanyol basını Osmanlı Devleti ve Türkiye ile ilgili zengin bir arşiv içeriği sunmaktadır. Osmanlı Tarihi ve Türkiye tarihiyle ilgili olarak yapılacak çalışmalara destek olmak ve bu alana katkı sağlamak bu çalışmanın en temel amacıdır. Ayrıca bu çalışma vesilesiyle Osmanlı Devleti'nin özellikle son yüzyılıyla ilgili zengin bir içerik sunan İspanyol basınını araştırmacıların dikkatine sunulması da hedeflenmiştir. İspanyol gazetelerine İspanya'nın milli kütüphanesi olan Biblioteca Nacional De España üzerinden ulaşılabilir. Biblioteca Nacional De España İspanya'da yayınlanan tüm kitapların ve yayınların kopyalarını alıp saklayan bir kurumdur. Merkezi Madrid'de bulunan kurum ayrıca el yazmaları, resimler, çizimler, fotoğraflar, ses kayıtları, müzik notaları gibi çok değerli bir koleksiyona sahiptir. ${ }^{14}$ Burada 1683 yılından günümüze kadar İspanya'da yayınlanmış süreli yayınlara ulaşmak mümkündür.

Biblioteca Nacional De España bağlı olarak faaliyette bulunan Biblioteca Digital Hispánica arşivinde yer alan İspanya'da yayımlanmış süreli yayınlarda II. Abdülhamid'in tahta bulunduğu dönem içinde (31 Ağustos 1876-27 Nisan 1909) Abdülhamid (Abdul-Hamid) kelimesi 1.192 kez geçmektedir. ${ }^{15}$ Aynı dönemde "hamid" olarak tarama yapıldığında 1.694 sonuç elde edilmesine rağmen "hamid" kelimesinin geçtiği bazı haberlerin II. Abdülhamid'le ilgisi olmadığından bu çalışmada "Abdul-Hamid" kelimesi esas alınmıştır. ${ }^{16} \mathrm{Bu}$ dönemde Osmanlı

\footnotetext{
${ }^{9}$ Age, s.79-80.

${ }^{10}$ Lewis, age, s. 160 .

${ }^{11}$ Lewis, age, s. 161.

${ }^{12}$ El Siglo Futuro, 30 Ağustos 1876, s. 3.

${ }^{13}$ Cevdet Küçük, “Abdülhamid II", DİA, İstanbul 1988, C.I, s.217.

${ }^{14} \mathrm{http}: / /$ www.bne.es/es/LaBNE/index.html. (E.T. 06.05.2019)

${ }^{15}$ http://hemerotecadigital.bne.es/results.vm? $\mathrm{o}=\& \mathrm{w}=$ Abdul-

Hamid\& $\mathrm{f}=$ text $\& \mathrm{~d}=$ creation $\& \mathrm{~d}=1876 \& \mathrm{~d}=08 \& \mathrm{~d}=31 \& \mathrm{~d}=1909 \& \mathrm{~d}=04 \& \mathrm{~d}=27 \& \mathrm{t}=\% 2$ Bcreation $\& \mathrm{l}=600 \& \mathrm{l}=700 \& \mathrm{~s}=0 \& 1 \mathrm{a}$ ng=es (E.T. 06.05.2019)

${ }^{16} \mathrm{http}: /$ hemerotecadigital.bne.es/results. $v \mathrm{~m} ? \mathrm{o}=\& \mathrm{w}=$ hamid\&f $=$ text\&d=creation $\& \mathrm{~d}=1876 \& \mathrm{~d}=08 \& \mathrm{~d}=31 \& \mathrm{~d}=1909 \& \mathrm{~d}=$ $\underline{04 \& \mathrm{~d}=27 \& \mathrm{t}=\% 2 \mathrm{Bcreation} \& \mathrm{l}=600 \& \mathrm{l}=700 \& \mathrm{~s}=0 \& \text { lang }=\mathrm{es}}$ (E.T. 06.05.2019)
} 
(otomano) kelimesi $16.982 \mathrm{kez}{ }^{17}$ Türkiye (Turquía) kelimesi ise 50.210 kez geçmektedir. ${ }^{18}$ Osmanlı Devleti’nin son elli yılında (1 Ocak 1872- 31 Aralık 1922) Türkiye (Turquía) kelimesi $82.587^{19} \mathrm{kez}$ Osmanlı (otomano) kelimesi $23.835 \mathrm{kez}^{20}$ ve Abdülhamid (Abdul-Hamid) kelimesi de $1.928 \mathrm{kez}$ İspanya'da yayımlanmış süreli yayınlarda geçmektedir. ${ }^{21} \mathrm{Bu}$ verilerden de anlaşılacağı üzere İspanyol basınında II. Abdülhamid ve dönemiyle ilgili yüzlerce haber ve yazı yayımlanmıştır. Dolayısıyla konunun tam manasıyla anlaşılması geniş çaplı bir araştırma ve çalışma yapmayı gerekmektedir. Yapılacak bu geniş çaplı araştırma bu çalışmanın sınırlarını oldukça aşacağından çalışma kapsamında 1876-1918 yıllarında arasındaki dönemde İspanyol basınında II. Abdülhamid'le ilgili çıkan haberler üzerinde yoğunlaşılmıştır. II. Abdülhamid'in adının geçtiği erişilebilir haberler tek tek incelenmeye çalışılmış ve haberler konu başlıklarına göre tasnif edilmiştir. Bu haber ve yorum yazılarının bir kısmı uzun bir kısmı da kısa haberler olarak gazetelerde yer almıştır. İspanyol basının doğrudan İstanbul' dan ilettiği haberler olmakla beraber Fransız, Alman, Avusturya basınından alıntıladığı haberlerde bulunmaktadır. Çalışma kapsamında haberler analiz edilmiş ve belirli konu başlıkları altında incelenmiştir. Gazetelerde yer alan haberlerdeki bilgilerin doğrulukları konuyla ilgili yapılmış başka çalışmalarla karşılaştırılmalı olarak incelenmiş ve ihtiyaç duyulan noktalarda da açıklamalar yapılmıştır. Bu yapılırken İspanyol gazetelerindeki ifade ve bilgiler aynen korunmuştur. Bu yüzden metin içerisinde geçen Türk, Türkiye, Türkiye Sultanı gibi kavramlar İspanyol gazetelerinde geçtiği şekliyle kullanılmıştır.

\section{Sultan Abdülhamid'in Kişisel Özellikleri ve Saraydaki Yaşantısı}

Osmanlı ve İspanya devletlerinin politika ve tarihlerinde dikkate değer bir paralellik vardır. ${ }^{22}$ Her iki devletle XIX. yüzyılda ihtişamlarını kaybederek güçten düşmüşler ve bu yüzyılın sonunda hızlı bir çöküş dönemine girmişlerdir. ${ }^{23} \mathrm{Bu}$ durum iki devletin benzer süreçlerden geçmesine zemin hazırlamıştır. Nitekim iki devletin aynı dönemde benzer liberal değişimler geçirmeleri ve aralarındaki benzerlikler nedeniyle her iki ülkenin kamuoyu

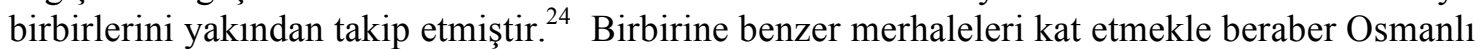
Devleti daima İspanya'dan önce davranmıştır." ${ }^{25}$ Ayrıca II. Abdülhamid'in tahta çıktığında pek tanınan biri olmaması dönemin basını kendisine yoğun bir ilgi göstermesine ve onunla ilgili birçok haberi sayfalarına taşımalarına zemin hazırlamıştır. La Epoca gazetesi Sultan Abdülhamid'in 12 Eylül 1842 'da doğduğunu ve yakında 34 yaşında olacağını okuyucularına duyurmuştur. ${ }^{26}$ La Iberia gazetesi ise Osmanlı İmparatorluğu'nun başında bulunacak olan prens

${ }^{17} \mathrm{http}: / /$ hemerotecadigital.bne.es $/$ results.vm?o=\&w=otomano $\& \mathrm{f}=$ text $\& \mathrm{~d}=$ creation $\& \mathrm{~d}=1876 \& \mathrm{~d}=08 \& \mathrm{~d}=31 \& \mathrm{~d}=1909 \&$ $\mathrm{d}=04 \& \mathrm{~d}=27 \& \mathrm{t}=\% 2 \mathrm{Bcreation} \& \mathrm{l}=600 \& \mathrm{l}=700 \& \mathrm{~s}=0 \&$ lang $=$ es $($ E.T. 06.05.2019)

${ }^{18} \mathrm{http} / /$ hemerotecadigital.bne.es $/$ results.vm? $\mathrm{o}=\& \mathrm{w}=$ Turqu $\% \mathrm{C} 3 \% \mathrm{ADa} \& \mathrm{f}=$ text $\& \mathrm{~d}=$ creation $\& \mathrm{~d}=1876 \& \mathrm{~d}=08 \& \mathrm{~d}=31 \&$ $\mathrm{d}=1909 \& \mathrm{~d}=04 \& \mathrm{~d}=27 \& \mathrm{t}=\% 2 \mathrm{Bcrea}$ tion $\& \mathrm{l}=600 \& \mathrm{l}=700 \& \mathrm{~s}=0 \&$ lang $=$ es $($ E.T. 06.05 .2019$)$

${ }^{19} \mathrm{http} / /$ hemerotecadigital.bne.es $/$ results.vm? $\mathrm{o}=\& \mathrm{w}=$ Turqu $\% \mathrm{C} 3 \% \mathrm{ADa} \& \mathrm{f}=$ text $\& \mathrm{~d}=$ creation $\& \mathrm{~d}=1876 \& \mathrm{~d}=08 \& \mathrm{~d}=31 \&$ $\mathrm{d}=1909 \& \mathrm{~d}=04 \& \mathrm{~d}=27 \& \mathrm{t}=\% 2 \mathrm{Bcreation} \& \mathrm{l}=600 \& \mathrm{l}=700 \& \mathrm{~s}=0 \&$ lang $=$ es $($ E.T. 06.05 .2019$)$

${ }^{20} \mathrm{http}: / /$ hemerotecadigital.bne.es/results.vm? $\mathrm{o}=\& \mathrm{w}=$ otomano $\& \mathrm{f}=$ text $\& \mathrm{~d}=$ creation $\& \mathrm{~d}=1872 \& \mathrm{~d}=01 \& \mathrm{~d}=01 \& \mathrm{~d}=1922 \&$ $\mathrm{d}=12 \& \mathrm{~d}=31 \& \mathrm{t}=\% 2$ Bcreation $\& \mathrm{l}=600 \& \mathrm{l}=700 \& \mathrm{~s}=0 \&$ lang $=$ es $($ E.T. 06.05 .2019$)$

${ }^{21}$ http://hemerotecadigital.bne.es/results.vm? $=\& \mathrm{w}=$ Abdul-

Hamid\& $\mathrm{f}=$ text $\& \mathrm{~d}=$ creation $\& \mathrm{~d}=1872 \& \mathrm{~d}=01 \& \mathrm{~d}=01 \& \mathrm{~d}=1922 \& \mathrm{~d}=12 \& \mathrm{~d}=31 \& \mathrm{t}=\% 2$ Bcreation $\& \mathrm{l}=600 \& \mathrm{l}=700 \& \mathrm{~s}=0 \&$ la ng=es (E.T. 06.05.2019)

${ }^{22}$ Muzaffer Arıkan, "XIV- XVI. Asırlarda Türk-İspanyol Münasebetlerine Toplu Bir Bakış”, Ankara Dil Tarih Coğrafya Fakültesi Dergisi, Ankara 1965, C.XIII, S.3-4 s.239.

${ }_{23}$ Victor Morales Lezcano, “İspanya Ve Türkiye: Birbirlerini Tanımamazlıktan Yakınlaşmaya Doğru”, OTAM Dergisi, Ankara 1991, C.II, s.218.

${ }^{24}$ Tufan Turan, “Midhat Paşa'nın Azli ve Sürgününün İspanyol Basınındaki Yansımaları ve Paşa'nın İspanya Seyahati", History Studies, Volume 6, Issue 4, July 2014, s.201-202.

25 Muzaffer Arıkan, "Türk-İspanyol Münasebetleri Bakımından Aragon Kraliyet Arşivi’nin Ehemmiyeti Ve Türklerle İlgili Vesikalar" Ankara Üniversitesi Tarih Araştırmaları Dergisi, 1964, C.II, s.252.

${ }^{26}$ La Epoca, 2 Eylül 1876, s.3. 
için okurlarına birçok ayrıntı vermek istediğini ancak gelen bilgilerin çok çelişkili olduğunu yazmıştır. Gazete Abdülhamid ile ilgili kimsenin şüphe etmediği tek bilginin onun 22 Eylül 1842 'de doğduğu bilgisi olduğunu belirtmiştir. ${ }^{27}$ Ancak her iki gazetenin verdiği doğum tarihide yanlıştır. II. Abdülhamid 21 Eylül 1842 'de dünyaya gelmiştir. ${ }^{28}$ Gazetelerin Yeni Sultan ile ilgili ayrıntı verememesinde Abdülhamid taht için adı geçen şehzadelerden biri olmaması ve Osmanlı'yı fazla tanımamaları etkili olmuştur.

Abdülhamid'in babası Abdülmecid, annesi Tirimüjgan Kadın Efendi'dir. ${ }^{29}$ Çocuk yaşta annesini kaybeden ve babasının ikinci eşi Piristû Kadınefendi tarafından büyütülen Abdülhamid Türkçe, Arapça, Farsça, Fransızca, Musiki, Tarih ve diğer ilim alanlarında eğitimler almıştır. ${ }^{30}$ Hayatının ilk yılları mutluluk ve huzur içinde geçen Abdülhamid çok erken yaşlardan itibaren haremin yolsuzluğuna alışmıştır. ${ }^{31} 1861$ 'de babasının ölümü üzerine Maslak'taki köşk, Tarabya'daki yazlık ile Kâğıthane'deki çiftliğinde yaşamaya başlayan Abdülhamid kendisine tahsis edilen aylık ve çiftliği işleterek hatırı sayılır bir servet elde etmiştir. "Saray halkı ve devlet büyükleri zeki, fakat düşünce ve kanaatlerini asla dışa vurmayan Şehzade Abdülhamid'i pek sevmezdi. Bu yüzden herkesin uzak kaldığı bu akıllı şehzade, ancak Pertevniyal Kadın'ın yardımı ile Sultan Abdülaziz'e yaklaşabilmiştir". ${ }^{33} \mathrm{Bu}$ sayede Şehzade Abdülhamid 1867 'de Sultan Abdülaziz'le Paris'e gidebilmiştir. ${ }^{34}$ Abdülhamid bu seyahatte gezdiği ülkeleri birbiriyle karşılaştırmış ve Osmanlı Devleti'nin gerilemesinin nedenlerini anlamaya çalışmıştır. ${ }^{35}$

El Pabellon Nacional gazetesi Abdülhamid'in olağanüstü fiziksel benzerliğe rağmen kardeşi V. Murad'dan birçok yönden farklı olduğunu yazmıştır. "Murad utangaç, hasta ve kayıtsız iken Abdülhamid çok enerjik, sağlam ve coşkuludur" diyen gazete Abdülhamid'in dindar bir insan olduğunu da yazmıştır. ${ }^{36}$ El Imparcial gazetesi Abdülhamid'in tutku ve eylem adamı olduğunu, sağlık ve vücut egzersizlerini sevdiğini yazmıştır. ${ }^{37}$ "Orta boylu bir adam olan Abdülhamid'e ince yüzü, büyük siyah gözleri ve uzun sakalı son derece enerjik bir görünüm vermektedir" diyen La Epoca gazetesi Abdülhamid hakkında geniş bilgi vermiştir. ${ }^{38}$ Gazete modern olan her şeyin Sultanın ilgisini çektiğini ve her ne kadar tutumlu olsa da merakını tatmin etmek için hiçbir masraftan kaçınmadığını belirtmiştir. "Hareminde çok sayıda odalık olsa da o en sevdiği eşi ile huzurlu bir hayat yaşıyor" diyen gazete Abdülhamid'in 6 yaşında bir oğlu ve 3 yaşında bir kızı olduğunu yazmıştır. Ayrıca Abdülhamid'in zamanının çoğunu eskrim, avlanma ve egzersizlere ayırdığını, evcil hayvanlara özel bir ilgi duyduğunu da belirtmiştir. ${ }^{39}$ Yıldız Sarayı

${ }^{27}$ La Iberia, 2 Eylül 1876, s.2.

${ }^{28}$ Küçük, agm, s.216.

${ }^{29}$ Küçük, agm, s.216.

${ }^{30}$ La Epoca, 2 Eylül 1876, s.3; Küçük, 1988, s.217.

${ }^{31}$ La Epoca, 2 Eylül 1876, s.3.

${ }^{32}$ Engin Akarlı, "II. Abdülhamid: Hayatı ve İktidar", Ed. Güler Eren, Osmanlı, Yeni Türkiye Yayınları, Ankara 1999, C.II, s.253.

${ }^{33}$ Küçük, agm, s.217.

${ }^{34}$ La Epoca, 2 Eylül 1876, s.3. Bu seyahat hakkında bakınız; Halîmî Efendi’nin “Sultan Abdülaziz Han Hazretlerinin Avrupa Seyahatnamesi" adlı eserin Necip Asım Yazıksız tarafından "Cennet-mekân Firdevs-i Âşiyân Sultan Abdülaziz Han Hazretlerinin Avrupa Seyahatnamesi” adıyla Tarih-i Osmâni Encümeni Mecmuası'ında yayınlanan eser (http://isamveri.org/pdfosm/D02076/1335-1338 49-62/1335-1338 49-62 ASIMN2.pdf); Osman Köksal,

"Sultan Aziz'in Avrupa Seyahati Dönüşü Münasebetiyle Yapılan Kutlamalar ve Bir Manzum Tarihçe", Osmangazi Üniversitesi Sosyal Bilimler Dergisi, C:IV S.1, Haziran 2003, s.117-136.

${ }_{35}$ Akarl1, agm, s.254.

${ }^{36}$ El Pabellon Nacional, 6 Ağustos 1876, s.2.

${ }^{37}$ El Imparcial, 1 Eylül 1876, s.1.

${ }^{38}$ La Epoca, 3 Eylül 1876, s.2; Konu ile ilgili geniş bilgi için bakınız: Metin Hülagü "Bir İnsan Olarak Sultan II. Abdülhamid”, Devr-i Hamid Sultan II. Abdülhamid, Erciyes Üniversitesi Yayınları, C.III, s.223-242.

${ }^{39}$ La Epoca, 3 Eylül 1876, s.2. 
bahçelerinde birçok farklı hayvan türünü getirten II. Abdülhamid bu hayvanlar için Kuşluk-1 Hümâyûn teşkilatını kurmuştur. Buradaki hayvanlar sarayın ihtiyacını karşıladığı gibi saray dışına da satılmıştır. Ayrıca burada çoğaltılan hayvanlar ülkenin farklı bölgelerindeki çiftliklere gönderilerek hayvancılığın gelişmesine katkı verilmiştir. ${ }^{40}$

İyi bir müzik ve tiyatro tutkunu olan II. Abdülhamid, sanatçıları ve sanatı desteklemiştir. ${ }^{41}$ Abdülhamid'in en büyük zevki marangozluktu. Ayrıca padişah zabıta ve cinayet romanları ile seyahatname kitaplarını dinlemeyi severdi. ${ }^{42}$ La Union gazetesi Sultan Abdülhamid'in özel hayatıyla ilgili okuyucularına ayrıntılı bilgiler aktarmıştır. Padişahın kaprisli bir insan olmadığını yazan gazete Abdülhamid'in Avrupa'dan getirtilen ama lüks olmayan bir masası olduğunu, saraydaki at ve arabaların sayısını önemli ölçüde azalttığını, mücevher ve resim gibi lüks eşyalarının olmadığından bahsetmiştir. Sultan Abdülaziz ve çevresinin partiler düzenleyip çok harcama yapmasına rağmen II. Abdülhamid'in mütevazı davrandığını ancak buna rağmen sarayda çok fazla miktarda tüketim yapıldığını yazmıştır. Gazete bu tüketimin çok olmasını Abdülhamid'in kendisine değil Sultan Abdülaziz'in çocukları ve akrabaları için çok harcama yapmasına bağlamıştır. ${ }^{43}$ La Iberia gazetesi ise II. Abdülhamid'in çok korkmasının onun iyi niteliklerini gizlediğini ileri sürerek bu kusurun onun resmi ve özel hayatını büyük ölçüde etkilediğini yazmıştır. Komploların bu baskıyı artırdığını yazan gazete II. Abdülhamid'in tahta çıkmasından önce ve sonrasında yaşanan olayların Sultanın Yıldız'da yaşamasını haklı çıkarabileceğini dile getirmiştir. ${ }^{44}$ Nitekim II. Abdülhamid'e karşı birçok suikast girişimin olması onun bu endişelerinde haksız olmadığını ortaya koymaktadır. Bu suikast planlarının bir kısmı onun "saltanatını sona erdirip yerine V. Murad ya da Reşad Efendi gibi şehzadeleri başa geçirmek amacıyla tasarlanmışken", diğer kısmı da Ermeni, Bulgar, Rus ve diğer yabancı komiteler tarafından hazırlanmıştır. ${ }^{45}$

İspanyol basını Ocak 1905'te Sultan Abdülhamid'in felç geçirdiği ve bunun kalp bölgesini etkilediği, Bakanlar Kurulu'nun Abdülhamid öldüğü zaman onun yerine kardeşi Reşad Efendi'yi V. Muhammed adıyla sultan ilan edeceğine dair haberler yapmıştır. ${ }^{46} \mathrm{Bu}$ iddialar daha sonları Türk elçilikleri tarafından yalanlanmasına rağmen birçok muhabir Sultan Abdülhamid'in hastalığının kötüleştiği ve her an ölebileceği konusunda 1 srar etmişlerdir. ${ }^{47}$ Ancak bu haberlerin çok doğru olmadığı daha sonra anlaşılmıştır.

Avrupa basını önceki padişahlardan farklı olarak II. Abdülhamid'in yaşantısıyla yakından ilgilenmiştir. La Iberia gazetesi Sultan Abdülhamid'in saray hayatıyla ilgili geniş bir değerlendirme yapmıştır. Önceki dönemlerde sarayın eğlencelerin yaşandığı bir yer olduğunu yazan gazete devlet işlerinin daha çok Bâbıâli tarafindan yapıldığını ve sadece olağanüstü durumlarda Padişah Konseyi'nin sarayda toplandığını yazmıştır. II. Abdülhamid döneminde ise sarayın ofisleri ve farklı türdeki bölümleriyle bir bakanlık haline geldiğini yazan gazete padişahın yurtiçinde ve yurtdışında meydana gelen önemli olan her şeyi bilmek istediğini aktarmıştır. Valilerinin, ordu birlikleri komutanlarının ve yurtdışındaki temsilcilerin telgrafla doğrudan Sultan ile iletişim kurduklarını anlatan gazete ciddi bir haber alındığında katı emirler

\footnotetext{
${ }^{40}$ Diren Çakılc1, "Sultan II. Abdülhamid'in Hayvan Merakı: Yıldız Sarayı'nda Kuşluk-1 Hümâyûn Teşkilatı”, Tarih Dergisi, İstanbul 2018, S.68 (2018/2), s.57-100.

${ }^{41}$ La Epoca, 21 Haziran 1891, s. 2; La Iberia, 27 Aralık 1893, s. 2.

42 Ali Akyıldız, “II. Abdülhamid'in Çalışma Sistemi, Yönetim Anlayışı ve Bâbıâli’yle (Hükümet) İlişkileri” Ed. Güler Eren, Osmanl, Yeni Türkiye Yayınları, Ankara 1999, C.II, s.289.

${ }^{43}$ La Union, 20 Şubat 1880, s.1.

${ }_{45}^{44}$ La Iberia, 27 Aralık 1893, s.2.

${ }^{45}$ Nurdan İpek Şeber, "Namlunun Ucundaki Padişah: II. Abdülhamid'e Karşı Planlanan Suikastler", Türkiyat Mecmuası, 2012, C.XXII, S.1, s.33.

${ }^{46}$ La Epoca, 1 Şubat 1905, s.1.

${ }^{47}$ La Epoca, 14 Ağustos 1906, s.1.
} 
sayesinde görevlilerin gece yarısı bile olsa bunu Sultan'a iletmekle mükellef olduklarını belirmiştir. ${ }^{48}$ El Dia gazetesi daha önce sadrazamların devlet içindeki etkinliklerine atıfta bulunarak Abdülhamid döneminde sadrazamın hiç sayılmadığını, bakanların ise isimlerinin bile bilinmediğini, yabancı ulusların artık sadrazam veya bakanlarla değil, doğrudan Sultanla veya en çok da Abdülhamid'in zeki ve kurnaz sırdaşı olan Mâbeyn-i Hümâyun Başkâtibi Tahsin Bey ile ilgilendiğini yazmıştır. ${ }^{49}$ II. Abdülhamid tahta çıktıktan sonra iktidarını sağlamlaştırmak için ilk olarak bazı imtiyazlar dağıtarak işe başlamış, anayasayı muhaliflere karşı kullanmış, ordunun kontrolünü ele geçirmiş, Sarayı Yıldız'a taşımış, harem ağaların rolünü azaltmış, Valide sultanın iktidarına son vermiştir. ${ }^{50}$ Nitekim Abdülhamid izlediği girift politikalar, jurnal rejimi, sık sık değiştirdiği sadrazamlar sayesinde temel iktidar mercii olarak kalmayı başarmıştır. ${ }^{51}$ Abdülhamid, Abdülaziz'in işlerin yönetimi bıraktığı Ali, Fuad, Mahmud, Hüseyin Avni ve Mithat Paşa gibi devlet adamlarını rüşvet almakla, ülkeyi borç batağına ve savaşa sürüklemekle suçlamış ve bu yüzden Bâbıâli'nin yetkilerini yavaş yavaş sarayda toplamıştır. ${ }^{52}$ Gazete bu diktatörlüğün imparatorluk için faydalı olabileceğini ancak Sultan'ın çok panik biri olması sebebiyle siyaset ve idarenin tüm sorunlarını kendi kişisel güvenliğini koruyacak önlemler alınmaya indirgediğini ileri sürmüştür. ${ }^{53}$ La Iberia gazetesi Padişahın çok çalışkan biri olduğunu yazmış ve onun İstanbul'da çıkan bir yangınla bile ilgilendiğini belirterek şöyle demiştir:

HISTORY STUDIES

921

Volume 11

Issue 3

June

2019

"Bu şekilde çalışan ve bu kadar ciddi sorumluluklar üstlenen bir erkeğin, kadınlara fazla zaman ayıramadığ anlaşılmaktadır. Elbette, Abdülhamid'in bir münzevi hayatı yok; ama zevklerini asla kötüye kullanmadığından emin olabilirsiniz. Bu belki de kusursuz sağllk durumunun sırrıdır. Normal alışkanlıkları, jimnastik yapması, sağlam yapısı ve gergin mizacı onu tehlikeli düşmanlıklardan kurtarlyor. Tahta çıktı̆̆ günden bu yana, yani, on yedi yıl boyunca, Abdülhamid, ciddi bir hastalık geçirmedi. Sultan, kırk yll hüküm süreceği inancına sahiptir; korkunç bir korkuya neden olan kolera hariç tüm hastalıklara önem vermez, çünkü o kolera salgının kurbanı olarak öleceğini öngören bir derviş. Bu öngörü, kolera Avrupa'yı tehdit ettiği ve bazen İstanbul'un kapılarına ulaştığında, bulaşmayı önlemek için büyük önlemler alınmasının ve alınmaya devam edilmesinin nedeni olmuştur... Sultan yataktan çok erken kalkar, meyveli bir kahvaltı yapar ve ofisine kapanır. Abdülhamid'in çalışması, diğer Avrupa hükümdarları gibi bir şey değil... Neredeyse her gün yabancl gazeteleri okur". ${ }^{54}$

Gazete Sultan Abdülhamid'in koleradan çekindiğini belirtmekle beraber II. Abdülhamid, anne ve babasının veremden ölmüş olmalarından dolayı koleradan değil daha çok veremden çekinmiştir. Hatta bu durum onu genç yaşından itibaren temkinli yaşamaya sevk etmiştir. ${ }^{55}$ Gazete Abdülhamid'in saraydaki çalışma hayatı hakkında da geniş bilgi vermiştir. Buna göre; sarayın başkâtibi olan Süreyya Paşa, Abdülhamid'in ofisine giderek farklı bakanlıklarda yapılan önemli işleri kendisine sunmaktaydı. Süreyya Paşa'nın ardından bakanlar, emirleri doğrudan Sultan'dan almak için Abdülhamid'in ofisine girmekteydiler. Sultan'in huzurunda tartışma ya da konuşmanın olmadığını aktaran gazete yalnızca bakanların, Sultan'ın kendilerine sorduğu sorulara cevap verdiğini ve bunu da ancak söyleyecekleri önemli bir şey varsa, çok çekingen ve az sözle yaptıklarını yazmıştır. "Konuşkanlık Türk siyasetçilere kariyerlerinde çok

${ }^{48}$ La Iberia, 27 Aralık 1893, s.1.

${ }^{49}$ El Dia, 13 Ağustos 1902.

${ }^{50}$ Fraçois Georgeon, "II. Abdülhamid”, Ed. Güler Eren, Osmanll, Yeni Türkiye Yayınları, Ankara 1999, C.II, s.258.

${ }^{51}$ Hamit Bozarslan, Türkiye Tarihi, İletişim Yayınları, İstanbul 2015, s.154-160.

${ }^{52}$ Akyıldız, agm, s.288.

${ }^{53}$ El Dia, 13 Ağustos 1902.

${ }^{54}$ La Iberia, 27 Aralık 1893, s.1.

${ }^{55}$ Küçük, agm, s.273. 
yardımcı olan bir durum değildir" diyen gazete Sadrazamın başkanlığında ki Bakanlar Kurulu'nun her zaman Abdülhamid'in ofisine bitişik bir odada bulunduğunu, bakanların Sultan'1 göremediğini, ancak Sultan'ın onların yaptıklarını görebildiğini yazmıştır. ${ }^{56}$

\subsection{Sultan Abdülhamid'in Tahta Çıkışının 25. Yıl Törenleri ve Cuma Selamlı̆̆ı Töreni}

Sultan Abdülhamid'in tahta çıkmasının 25. yıldönümü etkinlikleri İspanyol gazetelerine yansımıştır. Haberler incelendiğinde İstanbul'da yapılan kutlamaların çok parlak geçtiği anlaşılmaktadır. Kutlamalar çerçevesinde İstanbul'daki bütün evler süslenmiş, boğazda ve Haliç’te savaş gemileri demirlemiştir. Törenlerin merkezi ise Yıldız Sarayı olmuştur. Tören için sabah saat on birde sadrazam ve diğer devlet erkânı sarayda toplanmıştır. Öğlen saatlerinde sarayda dışişleri bakanlarının ve büyükelçilerin katıldığ 1 Avrupa, Amerika ve İran Devlet Başkanları tarafindan gönderilen özel temsilcilerden oluşan heyet için resmi bir kabul töreni yapılmıştır. Temsilciler, Sultan tarafından kıdem sırasına göre kabul edilmiştir. Saraydaki tören Osmanlı heyetlerinin kabulüyle sona ermiştir. Konuklar Sultan'a değerli hediyeler sunmuşlardır. Yemekten sonra, konuklar şehirdeki ana caddeleri gezmişlerdir. 25. yıl kutlamaları şerefine bir üniversite kurulmasına, Kâğıthane sularının şehre getirilmesine, yetimler için bir yetimhane, ticaret çıraklarına özel bir okul ve Beşiktaş'ta da bir okul ile bir cami yapılması karar verilmiştir. ${ }^{57}$

Türk sultanlarının dua etmek için her Cuma camiye gitmelerinin herkesçe malum olduğunu okuyucularıyla paylaşan El Liberal gazetesi Padişahın Cuma selamlığı hakkında ayrıntılı bilgi vermiştir. Padişahın Selamlık adı verilen muhteşem bir törenle saraydan ayrıldığını belirten gazete cami törenine katılmak istemeyen, ancak Sultanın geçişini izlemek isteyen yabancıların kendi elçiliklerinden, büyükelçiliklerinden veya konsolosluklarından izin belgesi almak zorunda olduklarını yazmıştır. İspanya Konsolosu Marquis de Herrera'dan bu izin belgesini (kartını) alan muhabir töreni izlemek için Hamidiye Camisi'ne gitmiş ve burada görevliler tarafından caminin girişinin önündeki bir bölüme yerleştirilmiştir. Padişah II. Abdülhamid'in, Abdülmecid'in Boğaziçi'nde yaptırdığı görkemli Saray olan Dolmabahçe'de değil küçük ama geniş bir park ve güzel bahçeleri olan zarif bir saray olan Yıldız'da yaşadığını anlatan muhabir daha sonda Cuma selamlığıyla ilgili gözlemlerini aktarmıştır. Camiden bakıldığında ağaçlı çiftlik evlerinin olduğu ve Pera'ya kadar uzanan tepeleri ve görkemli manzaraları anlatan muhabir gördüğü manzarayı bir tabloya benzetmiş̦tir. Boğazın ötesinde bahçelerin üzerinde minareleri yükselen Ayasofya'nın taçlandırdığı manzaradan da bahseden muhabir tören hazırlıklarının erken başladığını, yüksek rütbeli memurlar ile ulemadan birçok kişinin törende hazır bulunduğunu söylemiştir. Kurucusunun isminden dolayı Hamidiye Camii olarak adlandırılan cami ile Yıldız Köşkü ana kapısı arasında yaklaşık beş yüz adım olduğunu belirten muhabir Sultanın saraydan genellikle öğleden sonra on iki buçukta ayrıldığını yazmıştır. ${ }^{58}$

Çok sayıda misafir ve az sayıda pencere olduğu için töreni iyi bir yerden izlemek için tören alanına erken gitmek zorunda kaldığını anlatan muhabir törenin saat on ikide tören başladığını yazmıştır. Etrafta birçok Padişah koruması olduğunu anlatan muhabir çok sayıda genel memur ve genç deniz subayının tören kıyafetleri törene katıldığını belirtmiştir. Muhabir caminin yanındaki meydanda seçkin askerlerden oluşan ve çok gösterişli tören kıyafetleriyle iki süvari alayı geldiğini, saraydan önce imparatorluk alayının, arkasından Sultan'ın ve sonrasında da beyaz kenarlıklar ve yaşmaklarla örtülmüş arabaların içinde saray kadınları çıtığını anlatmıştır. Abdülhamid'in çok güzel bir siyah sakalının etkileyici olduğunu söyleyen muhabir

\footnotetext{
${ }^{56}$ La Iberia, 27 Aralık 1893, s.1-2.

${ }^{57}$ La Epoca, 4 Eylül 1900, s.1.

${ }^{58}$ El Liberal, 7 Temmuz 1896, s.1.
} 
sempatik ve biraz üzgün gözüken Padişahın törene katılanları yavaşça selamladığını belirten muhabir daha sonra Padişahın bulunduğu arabanın caminin basamaklarına vardığını ve Sultanın camiye geçtiğini anlatmıştır. Törende misafirlere kahve, çay ve dondurma ikram edilmiştir. Namazdan sonra Abdülhamid camiden çıkıp arabayla Yıldız Köşkü'ne gitmiş ve böylece tören bitmiştir. $^{59}$

\section{II. Abdülhamid Dönemi'nde Yaşanan Siyasi Olaylar ve Gelişmeler}

\section{1. Şehzade Abdülhamid'in Tahta Çıkışı ve Sonrasında Yaşanan Gelişmeler}

1876 yılı Osmanlı tarihinde üç padişahın görev yaptığı nadir bir yıl olmuştur. Padişah değişikliklerinin temel sebebi ise ülkede yaşanan tartışmalar, çekişmeler ile iç ve dış sorunlardır. Bu durum Sultan Abdülaziz'in tahtan indirilmesi ve yerine Şehzade Murad'ın tahta çıkarılması tartışmalarını beraberinde getirmiştir. Sultan Abdülmecid'in büyük oğlu V. Murad 21 Eylül 1840'da doğmuştur. Babasının ölümünden sonra kanun gereği ailedeki en yaşlı kişinin tahta çıkması gerektiği için tahta kendisi değil amcası Abdülaziz çıkmıştıR. ${ }^{60}$ Midhat Paşa "mevcut rejimden hoşnut olmayan ve kurtuluşu ancak meşrutiyet rejimde gören ulema, sivil ve askeri bürokrasiye mensup çevrelerle" yakın temasta bulunarak taht değişikliği için görüş̧ alışverişinde bulunmuştur. ${ }^{61}$ Midhat Paşa, padişah değişikliği olmadan Meşrutiyeti ilan etmenin mümkün olmadığını anlayınca Şehzade Murad ile görüşmüş ve Meşrutiyetin ilanı için kendisinden söz almıştır. Bu gelişmeden sonra 30 Mayıs 1876'da Sultan Abdülaziz'i tahttan indirilmiş ve Şehzade Murad tahta çıkarılmıştır. ${ }^{62}$

V. Murad'ın tahta çıkmasından kısa bir süre sonra ruh halinin giderek bozulması üzerine Midhat Paşa, "Bakanlar Kurulu ve Türk İmparatorluğu'nun büyük saygınları V. Murad'ı" tahtan indirmeye karar vermiştir. ${ }^{63}$ Nitekim V. Murad 31 Ağustos 1876 'da tahtan indirilmiş ve yerine Şehzade Abdülhamid tahta çıkarılmıştır. ${ }^{64}$ El Imparcial gazetesi bu değişikliği "Sultan Murad Han'ın tahta geçmesinden on gün sonra kendisini etkileyen amansız bir hastalık yüzünden imparatorluğun dizginlerini daha uzun süre korumasının imkânsızlığı sebebiyle Sultan II. Abdülhamid bugün Türkiye'nin İmparatoru ilan edildi” sözleriyle okuyucularına duyurmuştur. ${ }^{65}$ Doktor raporuyla V. Murad'ın üç ay dinlenmeye ihtiyacı olduğunu açıklanmasıyla halefi olan kardeşi Şehzade Abdülhamid'in yerini almasını değerlendiren $L a$ Ilustración Española y Americana gazetesi "hükümdarların hasta olduğu için görevden alındığ 1 bir ülkede neyse ki Abdülhamid jimnastik sevgisi sayesinde sağlıklı" değerlendirmesinde bulunmuştur. Gazete II. Abdülhamid'in ülkeyi yönetmenin ağır yükünü taşıyacağından kimsenin şüphesinin olmadığını Sultanın uzun uzun harita incelediğini, muhteşem koleksiyonları olduğunu ve bir papağanla oynayarak eğlendiğini yazmıştır. ${ }^{66}$

Sultan Abdülhamid Eyüp Sultan Camisi'nde düzenlenen törenle tahta çıkmıştır. ${ }^{67}$ Meşrutiyeti ilan etmek şartıyla tahta çıkarılmasına rağmen Abdülhamid, Midhat Paşa ve imparatorluğun kurtuluşunu anayasa kurumlarında ve parlamentarizmde arayan kişilerin görüşlerini paylaşmamıştır. ${ }^{68}$ II. Abdülhamid'in padişah olması Osmanlı Devleti'nin

\footnotetext{
${ }^{59}$ El Liberal, 7 Temmuz 1896, s.1.

${ }^{60}$ Turan Tufan, “İspanyolların Gözünden Osmanlı Devleti'nde 1876 Darbesi ve Sultan II. Abdülhamid'in Tahta Ç1kıș Süreci”, TAD, 2019, C.XXXVIII, S.65, s.289.

${ }^{61}$ Gökhan Çetinsaya; Ş. Turan Buzpınar, "Midhat Paşa”, DİA, İstanbul 2005, C.XXX, s. 8.

${ }^{62}$ Agm, s. 8-9.

${ }^{63}$ La Iberia, 2 Eylül 1876, s.2; El Siglo Futuro, 30 Ağustos 1876, s.3.

${ }^{64}$ El Imparcial, 31 Ağustos 1876, s.3; Revista de España, Eylül 1876, s.144.

${ }^{65}$ El Imparcial, 4 Eylül 1876, s.1.

${ }^{66}$ La Ilustración Española y Americana, 8 Eylül 1876, s.2.

${ }^{67}$ Crónica de Cataluña, 7 Eylül 1876, s.4; El Imparcial, 4 Eylül 1876, s.1.

${ }^{68}$ El Pabellon Nacional, 6 Ağustos 1876, s.2.
} 
kurtarılmasına yönelik umutları yeşertmiştir. ${ }^{69}$ Kritik koşullarda Osmanlı tahtına çıkan II. Abdülhamid ile ilgili okuyucuların bilgilendirmek isteyen La Iberia gazetesi padişahla ilgili çok çelişkili bilgiler geldiğini aktarmıştır. II. Abdülhamid hakkında değerlendirmelerde bulunan gazete bazılarının onun yardımsever, bazılarının da onun zorlu bir insan olduğu söylediğini ama birçoğunun onun zeki olduğu konusunda hemfikir olduğunu yazmıştır. ${ }^{70} \mathrm{La}$ Iberia gazetesi La Correspondéncia Política gazetesinden yaptığı alıntıda düzenli ve tutumlu biri olan II. Abdülhamid'in son iki hükümetin harabeye dönüştürdüğü yağma rejimini takip etmeyeceğini, örnek bir yönetim sergileyeceğini öne sürmüștür. Sultan Abdülhamid'e yönelik despotizm suçlamasının herhangi bir temele dayanmadığını belirten gazete Türk hükümet sistemini değiştirmeyi düşünmenin çok akıllıca olacağını ileri sürmüştür. Gazete ayrıca II. Abdülhamid'in tahta çıktıktan sonra ki siyasi amacının Türkiye'de mili birliği sağlamak olacağını söylemiştir. Bu görüşten farklı olarak La Ilustración De Leipzig gazetesi ise yüksek dehaya sahip olan Abdülhamid'in İslamcılığı ülkeye egemen kılacağını okuyucularına iletmiştir. $^{71}$

Sultan Abdülhamid'in padişah olduktan sonra aldığ 1 ilk kararlarından biri Mahmud Nedim Paşa'yı saraya çağırmak olmuştur. El Pabellón Nacional gazetesi "son zamanlarda Türkiye siyasetini bilenler böyle bir randevuyu kaçırmazlar" diyerek okuyucularına duyurmuş ve Mahmud Paşa'nın Rus ittifakının destekçisi olmasına dikkat çekmiștir. Bu görüşmenin Abdülaziz'in tahtına mal olan harekete hiç katılmadığ 1 düşünülen Abdülhamid hakkında şüphelere yol açabileceğini ileri sürerek Mahmud Nedim Paşa'nın atamasının politik kaygılarla yapılmış olabileceği yorumunda bulunmuştur. Gazete ayrıca İstanbul'da Rusya'ya karş1 suçlamaların her an arttığı bir ortamda bu atamanın iyi görünmemiş olabileceğini belirtmiştir. ${ }^{72}$

\subsubsection{Abdülhamid, Midhat Paşa ve Meşrutiyet'in İlanı}

Sultan Abdülaziz'in tahtan indirilip V. Murad'ın tahta çıkarılmasında etkili olan Midhat Paşa V. Murad'ın tahtan indirilip II. Abdülhamid'in tahta çıkarılmasında da rol oynamıștır. Ancak "Sultan Abdülhamid ve desteklerini aldığı Cevdet Paşa gibi muhafazakâr Tanzimatçılar ile Midhat Paşa ve taraftarları arasında Kanûn-1 Esâsî metni hakkında uzun süreli yoğun tartışmalar" yaşanmıştır. Tersane Konferansı'nın yapıldığ gün 23 Aralık 1876'da Kanûn-1 Esâsî ilân edilmiştir. "Midhat Paşa'nın beklentisi, etnik ve dinî ayırım gözetmeksizin bütün Osmanlı tebaasını aynı haklara sahip kılarak iç karışıklıkları sona erdirmek, böylece dış müdahalelere mazeret oluşturan sebepleri ortadan kaldırmaktı" ancak İngiltere ve Rusya'nın izlemiş olduğu politikalar bu beklentileri boşa çıkarmıştır. ${ }^{73}$

La Iberia gazetesi Midhat Paşa'nın kendi hakkındaki iddialara cevap vermek için Sultan Abdülhamid'e 4 Şubat 1877 'de yazdığı mektubu yayımlamıştır. Midhat Paşa Anayasanın sadece Şark meselesine son vermek amaciyla ilan edilmediğini, Padişaha ve ailesine saygı duyduğunu ve bu saygıyı ülkenin çıkarlarına aykırı bir araç haline getiremediğini belirtmiştir. Büyük bir sorumluluğu olduğunu söyleyen Midhat Paşa anayasal bir hükümet olduklarını söyleyerek Abdülhamid'e anayasanın anlamını sormuştur. ${ }^{74}$ Midhat Paşa'nın şahsi davranışları, padişaha sorumlu değilmiş gibi davranması, uzlaşmaz tavrı, saltanatı lağvedip cumhuriyeti ya da kendi diktatörlüğünü ilân edeceği dedikoduları, sert ve ağır bir dille kaleme alınmış ve içeriği basına sızdırılmış olan tezkiresini saraya sunduktan sonra konağına çekilip

\footnotetext{
${ }^{69}$ La Iberia, 20 Eylül 1876, s.2.

${ }^{70}$ La Iberia, 2 Eylül 1876, s.2

${ }^{71}$ La Iberia, 2 Eylül 1876, s.2.

${ }^{72}$ El Pabellón Nacional, 5 Eylül 1876, s.2; El Imparcial, 4 Eylül 1876, s.1.

${ }^{73}$ Küçük, agm, s.9.

${ }^{74}$ La Iberia, 22 Şubat 1877.
} 
padişahın davetlerini cevapsız bırakması üzerine 5 Şubat $1877^{\prime}$ de görevden alınmış ve yurt dışına sürgüne gönderilmiştir. ${ }^{75}$

Midhat Paşa Avrupa'nın çeşitli ülkelerinde yaklaşık bir buçuk yıl sürgün hayatı yaşamıştır. Sultan Abdülhamid Eylül 1878'de Paris'teki Osmanlı Büyükelçisi Arifi Paşa aracılığıyla Paris'te Montaigne caddesinde yaşayan Midhat Paşa'ya önemli bir mesaj iletmiştir. Yapılan görüşmede elçi Midhat Paşa ve ailesinin yeniden Osmanlı topraklarına girebileceğini ve Girit adasına yerleşebileceklerini iletmiş̧tir. Devlet Midhat Paşa ve ailesinin Girit'e gitmesi için bir gemi tahsis etmiştir. Midhat Paşa Eylül 1878 'in sonlarında Paris Marsilya yoluyla Girit'e gitmiştir. ${ }^{76} \mathrm{Bu}$ örnekte de görüldüğü üzere II. Abdülhamid'in muhalif bile olsa kimseyi kolay kolay gözden çıkarmadığı anlaşılmaktadır.

\subsection{Osmanlı-Rus İlişkileri}

XIX. yüzyılda yayılmacı bir politika izleyen Rusya'nın ana hedeflerinde biri sıcak denizlere inmekti. Bu amaçla defalarca Osmanlı Devleti'yle savaşan Rusya, Avrupa devletlerini aşamadığı için bu amacına ulaşamamıştır. Osmanlı sınırları içinde yaşayan Hristiyanları bahane ederek sık sık Osmanlı Devleti'nin içişlerine karışan Rusya, Osmanlı Devleti'nin toprak bütünlüğünden yana olan ve sıcak denizlere inmesinin önündeki en büyük engellerden biri olan İngiltere ile de anlaşmanın yollarını aramıştır. Nitekim Balkanlarda yaşanan gelişmelerin Avrupa kamuoyunda Türk karşıtı bir algının malzemesi haline gelmesi Rusya'yı harekete geçirmiş̧tir. Bunun üzerine İngiltere, Paris Antlaşması'nda imzası olan devletlerin İstanbul'da toplanmasını sağlamıştır. ${ }^{77}$ Ancak görüşmelerin başarısızlıkla sonuçlanması Osmanlı-Rus Savaşı'na zemin hazırlamıştır.

El Siglo Futuro gazetesi Rus Hükümetinin, Türkiye Hıristiyanlarının sadık ve özverili koruyucusu olmaya devam edeceğini açıkladığını, Staniforths, Roze ve Gate arasındaki görüşmelerin devam ettiğini ancak sonucun ne olacağının veya hangi koşullar altında olacağ bilinmediğini okuyucularına duyurmuştur. ${ }^{78}$ Rusya İstanbul Konferansı'nın başarısız olması sonucunda Osmanlı Devleti'nin yapılan teklifleri reddetmesi ve reformlara yanaşmaması bahanesiyle savaş hazırlıklarına başlamıştır. ${ }^{79}$ Rus mühendislerin Tuna'yı aşacak dubalar inşa ettiğini belirten El Siglo Futuro gazetesi savaş durumunda Osmanlı topraklarına yoğun bir göç olacağını, Rusya'nın Hristiyanları koruma bahanesiyle Türk topraklarını alarak hâkimiyet alanlarını daha da genişleyeceğini belirtmiştir. ${ }^{80}$

Bâbıâli'nin Avrupalı ortakları tarafından önerilen aşağılayıcı koşulları kabul veya reddetmeye karar vermediğini belirten El Siglo Futuro, Rusya'nın savaşı kazanması durumunda İngiltere'nin Mısır üzerindeki etkisini yitirebileceğini ve savaşın çıkarlarına zarar vereceğine yazmışıır. ${ }^{81}$ Rusya ve Balkan devletlerinin emellerine yakınlık duyan Lord Salisbury Bâbıâli'nin sunulan planı reddetmesi durumuna Rusya'nın Osmanlı Devleti'ne saldıracağını ve İngiltere'nin Osmanlı Devleti'ne yardım etmeyeceği tehdidinde bulunmuştur. ${ }^{82}$

Rusya'daki birliklerin hareketi hakkında haberler dolaşırken Osmanlı Devleti de savaştan

\footnotetext{
${ }^{75}$ Küçük, agm, s.9.

${ }^{76}$ La Iberia, 20 Eylül 1878, s. 2.

${ }_{77}$ Mithat Aydın, “İstanbul Konferansı”, DİA, Ek C.1, İstanbul 2016, s. 673.

${ }_{78}^{78}$ El Siglo Futuro, 18 Nisan 1876, s.2.

${ }^{79}$ Armaoğlu, age, s.507-518.

${ }^{80}$ El Siglo Futuro, 30 Kasim 1876, s.2.

${ }^{81}$ El Siglo Futuro, 29 Aralık 1876, s.2.

82 Standtford J. Shaw-Ezel Kural Shaw, Osmanlı Imparatorluğu ve Modern Türkiye, E Yayınları, İstanbul 1994, C.II, s.225.
} 
kaçınmanın yollarını aramıştır. ${ }^{83}$ Buna rağmen Rusya en üst düzeyde savaş hazırlıklarına devam etmiştir. Rus Çarı başkanlığında Don Kazakları, Senato Başkanı ve mahkeme üyelerinin katıldığı büyük bir konsey toplanmıștır. Konsey sonunda, İstanbul'daki Rus işletmelerinin Osmanlı bölgesini derhal terk etmeleri istenmiş ve ülke genelindeki birliklere seferberlik emri verilmiştir. Böylelikle Rusya fiili olarak Osmanlı Devleti'ne savaş ilan etmiştir. ${ }^{84}$ Nitekim kısa bir süre sonra Rusya 24 Nisan 1877'de Osmanlı Devleti'ne karşı resmen savaş ilân etmiştir.

Osmanl1-Rus savaşı İspanyol basınında geniş yer bulmuştur. El Siglo Futuro gazetesi Rusların Osmanlı'ya karşı savaştığını belirterek "Ruslar İstanbul'u işgal ettiğinde ve Osmanlı İmparatorluğu yıkıldığında, ne olacak? diye sormuştur. ${ }^{85} \mathrm{Bu}$ sorunun Avrupalı devletler tarafında yeterince düşünülmediği sonraki süreçte yaşanan olaylarla ortaya çıkmıştır. OsmanlıRus Savaşı Kafkasya ve Rumeli olmak üzere iki ana cephede olmuştur. Kars'ta yeterli bir garnizon bırakan Muhtar Paşa kuvvetlerini Kars-Erzurum arasında bir bölgeye çekmiş, Türkiye'de görev yapan 9 bin kişilik Mısır askerinin sayısı 12 bine çıkarılmış ve Türkler Bayazid'e yürümüşlerdir. ${ }^{86}$ El Siglo Futuro gazetesi Muhtar Paşa'nın süvarilerinin tamamen yok edildiğini ve Paşa'nın geri çekilmek zorunda kaldığını, Sultanın ciddi bir şekilde hasta olduğunu ve sadrazamın düşüşünün yakın olduğunu ileri sürmüştür. Gazete Boğaziçi ve Tuna arasında yerleşmiş olan tüm Türk İmparatorluğu'nun yıkılışının yakın olduğunu da iddia etmiştir. Kars'ın kuşatıldığını, Ardahan'ın kaybedildiğini, Türklerin zafer kazandığını iddia ettiği Karakilise savaşının da onlar için kötü gittiğini belirten gazete "şu andan itibaren Ermenistan'da Osmanlı ordusu için her şeyin kaybedildiğini söyleyemeyiz; her şey Türklerin tehlikeli bir durumda olduğunu gösteriyor" demiştir. ${ }^{87}$ Kafkas cephesinde bu gelişmeler yaşanırken Osmanlı Devleti Rumeli cephesinde de zor günler geçiriyordu. Rus birliklerinin Dobruca'ya girdiği ve Türk birliklerinin geri çekildiği sıralarda İngiliz filosu açık denizlere açılma emri almıştır. Basında filonun İstanbul'a gitmek için bir emir aldığına dair haberler çıkmıştır. El Siglo Futuro gazetesi “Türk kuvvetlerinin durumu ve Rus ordusunun İstanbul'a ilerlemesinin büyük olasılığı göz önüne alındığında, İngiliz filosunun böyle bir göreve gitmesinin kimseden gizlenmeyeceğini" belirtmiştir. ${ }^{88}$

Temmuz 1877'nin başlarında Rus ordusunun Balkanların kuzeyinden iki koldan ilerledikleri ve yakında Osmanlı ordusu ile karşılaşacakları basına yanmıştır. ${ }^{89} \mathrm{Bu}$ gelişmeler karşında II. Abdülhamid, Sultan Taburları olarak adlandırılacak Müslümanlar ve Hıristiyanlardan oluşan on yardımcı taburun derhal kurulması emrini vermiştir. ${ }^{90}$ Ancak alınan önlemler yeterli olmamış ve Türkler Dobruca'yı terk etmek zorunda kalmıştır. Ruslar, Edirne'ye gitmek üzere Yanbolu'ya yoğunlaşmış ve Tuna'yı geçen 50 bin kişilik bir Rus kuvveti Vidin üzerine yürümüştür. Osmanlı ordusu topraklarını kaybederken Rus ordusu Türk topraklarını kontrol etmeye başlamıştır. ${ }^{91}$ Buna rağmen Osmanlılar Rus ilerleyişini Plevne'de kısmen durdurulabilmiştir. El Siglo Futuro gazetesi Rusların burada 1.931 kayıp verdiğini, Albay Rosembon, Kleinhaus ve 14 memurun öldürüldüğünü, General Kouring ve 36 memurunda yaralandığını okuyucularına iletmiştir. Gazete Balkanların güneyinde Süleyman Paşa'nın 60 bin kişilik kuvvet topladığını, Rusların ise pozisyonlarını korumaya çalıştıklarını yazmıştır. ${ }^{92}$

${ }^{83}$ El Siglo Futuro, 3 Şubat 1877, s.3

${ }^{84}$ E1 Siglo Futuro, 17 Nisan 1877, s.3.

${ }^{85}$ El Siglo Futuro, 3 Mayis 1877, s.1.

${ }^{86}$ El Siglo Futuro, 7 May1s 1877, s.3; 4 Haziran 1877, s.3.

${ }^{87}$ El Siglo Futuro, 5 Haziran 1877, s.3.

${ }^{88}$ El Siglo Futuro, 3 Temmuz 1877, s.3.

${ }^{89}$ El Siglo Futuro, 11 Temmuz 1877, s.2.

${ }^{90}$ El Siglo Futuro, 20 Temmuz 1877, s.2.

${ }^{91}$ El Siglo Futuro, 21 Temmuz 1877, s.2.

${ }^{92}$ El Siglo Futuro, 28 Temmuz 1877, s. 2. 
Plevne'de yaşanan savaşta Osman Paşa'nın büyük bir zafer ilan ettiğini belirten El Siglo Futuro gazetesi iki gün süren savaşta Rusların 8 bin ölü, 16 bin yaralı verdiğini ve Rusların tamamen mağlup edildiğini yazmıştır. Osmanlı birliklerinin ise savunmada oldukları için daha az kayıp verdikleri belirten gazete "bu haberler abartılı bile olsa Osman Paşa'nın zafer kazandığı belli" demiş ve Türklerin Tuna Nehri'nden Balkanların ötesine uzanan düşman hattını Tırnova'da kesmek için büyük bir çaba sarf ettiğini eklemiştir. ${ }^{93}$ Bu arada Yunan Hükümetinin Alman fabrikalarına önemli miktarda silah siparişi verdiği ve amaçlarının Osmanlı ordusuna saldırmak olduğunu basına yansımıştır. ${ }^{94}$ Eylül 1877 'de İspanyol basınında Osmanlı askerlerinin Ruslardan Şipka geçidini almak için yoğun çaba harcadığı, Süleyman Hüsnü Paşa'nın burada büyük bir mücadele verdiği ve Osman Paşa'nın Ruslara karşı verdiği mücadele ayrıntılı olarak yansımıştır. ${ }^{95}$

Havas Ajansı ise 19 Ocak 1878'de Şerif Ali'nin Sultan Abdülhamid'de hitaben yazdı̆̆ mektubun bir bölümünü yayınlamıştır. Şerif Ali, Rusların ilerlediklerini belirtmiş ve tarafsız kalan İngiltere'yi eleştirerek 'İngiltere'nin en kritik anda size yardım etmediğini gördüğümde size olan hislerimi ifade edemem. Bir süredir İngilizlerin arkadaşlık bağlarını kolayca görmezden geldiğini ve vaatlerini yerine getirmediğini bilerek, harekete geçmeleri için çaba sarf ediyorum. Rusların İngilizler kadar güce sahip olduklarını, iyi niyette onları aştıklarını düşünüyorum ve ikincisinin vaatlerine güvenemem" diyerek İngiltere'nin dostluğunun boş bir laftan ibaret olduğunu ve İngilizlerin her zaman arkadaşlarını terk ettiğini ileri sürmüştür. Şerif Ali ayrıca Rus elçisiyle çok sayıda görüşme yaptığını ve bu görüşmelerde Rusların İngilizlerden daha dürüst ve daha samimi oldukları kanaatini elde ettiğini belirterek "bence İngiltere ile olan bütün ittifakları bitirin Ruslarla anlaşın" demiştir. ${ }^{96}$ Şerif Ali’nin Osmanlıları Rusların safına çekmek istediği görülmektedir.

Doksanüç Harbi sonucunda Osmanlı Devleti yenilmiş ve Rusya'yla 3 Mart 1878'de Ayastefanos Antlaşması'nı imzalamıştır. Ancak bu antlaşmayla Rusya'nın oldukça güçlü bir duruma gelmesi Avrupa devletlerini rahatsız etmiş ve Berlin Konferansı'nı toplamışlardır. Bu konferans sonucunda Ayastefanos Antlaşması'nın yerine Berlin Antlaşması imzalanmıştır. Osmanlı Devleti'nin savaş sonrasında ağır kayıplar yaşaması üzerine II. Abdülhamid ülkesinin ancak Avrupa devletlerinin çatışan menfaatlerini kullanarak izlenecek bir denge siyasetiyle ayakta kalabileceğini anlamıştır. Bu siyaset gereğince mümkün oldukça barış içinde yaşamak ve hiçbir devletle tam anlamıyla müttefik olmama politikasını takip etmiştir. II. Abdülhamid ayrıca büyük devletlerin Osmanlı Devleti'nin içişlerine karışmasına sebep olan sorunları da çözmeye çalışmıştır.

Doksanüç Harbi sonrasındaki süreçte de zaman zaman Ruslarla gerginlikler yaşanmıştır. Bu gerginliklere ağırlıklı olarak Balkanlarda yaşanan sorunlar ile Ermesi meselesi sebep olmuştur. El Siglo Futuro gazetesi “Rusya'nın Türkiye ile ilişkilerinde büyük bir gerginlik var. İki ülke arasında şimdiye kadar yürürlükte olan ticaret anlaşması henüz yenilenmedi, gümrük tarifelerinin yeni oranlarda uygulanması, Rus ithalatçılarını" olumsuz etkiledi ve Osmanlı İmparatorluğu'nun Ermeni sınırında Rus askerlerinin toplanması gelecekte sorunlara yol açabilir" dedikten sonra Bâbıâli'nin Moskova hükümetini isyancıları desteklemekle suçladığııı okuyucularına bildirmiştir. ${ }^{97}$ Berlin Antlaşması'yla büyük oranda toprak kaybeden Osmanlı Devleti Ermenilerin yaşadığ 1 yerlerde de reform yapmayı kabul etmiştir. La Epoca gazetesi Ermeni katliamı olduğunu iddia ederek Hıristiyanların katledilmesinin din savaşlarını

${ }^{93}$ El Siglo Futuro, 3 Ağustos 1877, s.2.

${ }^{94}$ El Siglo Futuro, 20 Ağustos 1877, s.3.

${ }^{95}$ El Siglo Futuro, 6 Eylül 1877, s.2.

${ }^{96}$ La Iberia, 10 Ekim 1878.

${ }^{97}$ El Siglo Futuro, 27 Mart 1883, s.2-3. 
canlandırdığını, üç yüz bin Ermeni'nin ölümünün ticaret, sanayi ve tarımı mahvettiğini ve Türkiye'nin yakında yıkılacağını ima etmiştir. ${ }^{98}$ Gazetedeki haberlere bakıldığında İspanyol basınında da diğer Avrupa devletlerinde olduğu gibi Hristiyanlarla ilgili meselelerde bir alg1 oluşturulmaya çalışıldığı görülmektedir. Başta İngiltere olmak üzere Avrupa devletleri II. Abdülhamid'e Berlin Antlaşması'nın 61. maddesini uygulamak için baskı yapmışlardır. İngiltere ve İtalya büyükelçileri tarafından yapılan girişimlerden sonra Türkiye Sultanı'nın Sadrazama Ermeni şikâyetlerinin dinlenerek adaletle gerekli tedbirleri alma emri verdiğini yazan La Epoca gazetesi "Sultan bazı ayrıcalıkların Ermenistan'ın lehine olduğunu ve bu durumun yabancı güçlerin içişlerine müdahalesine yol açtığını biliyor" yorumunu yapmıştır. ${ }^{99}$ $\mathrm{Bu}$ dolayı II. Abdülhamid bu meselesinin kullanılarak Osmanlının içişlerine karışılmasını engellemek için yapılacak reformların planlanmasında azami hassasiyet göstermiştir. ${ }^{100}$

İki ülke arasındaki gergin ilişkilere rağmen II. Abdülhamid ve III. Alexander aralarındaki iyi ilişkileri korumaya çalışmışlardır. Nitekim III. Alexander, II. Abdülhamid'e Rus büyükelçisi aracılığıyla hediye göndermiş ve ardından Osmanlı temsilcileri St. Petersburg'a gitmiştir. El Siglo Futuro bunun birkaç yıl önce şiddetli şekilde savaşan ülkeler arasındaki basit nezaket değişikliği olmadığını belirterek Bâbıâli ve Türkiye'nin Ayastefanos Antlaşması'ndan sonra Almanya ve Avusturya'yla olduğu gibi Rusya ile de samimi ilişkiler kurduğu yorumunda bulunmuştur. ${ }^{101}$ Osmanlı'nın bu ilişkileri kurmasında İngilizlerin Kıbrıs ile Mısır'ı işgali ve Osmanlı'nın toprak bütünlüğüne yönelik değişen politikası etkili olmuştur. ${ }^{102}$

\subsection{Balkanlarda Yaşanan Gelişmeler}

Fransız İhtilali sonrasında yayılan milliyetçiliğin ve Panslavizmin etkisiyle Balkan milletlerinin Osmanlı Devleti’nden ayrılmak için girişimleri artmıştır. Bu girişimlerin sonucu olarak Yunanistan'ın bağımsız olması diğer Balkan milletleri için örnek teşkil etmiştir. Osmanlı toprakları üzerinde farklı emelleri olan İngiltere, Rusya ve Avusturya Balkan milletlerini Osmanlı Devleti'ne karşı kışkırtmış ve isyanlarını desteklemiştir. Ayrıca bu devletler Osmanlı Devleti'ni Rumeli'de ıslahatlar yapması konusunda da baskı altına almaya çalışmışlardır. ${ }^{103} \mathrm{Bu}$ durum Balkanlarda yaşanan sorunların giderek büyümesine sebep olmuştur. Balkanlarda yaşanan sorunların başında Bosna ve Hersek, Karadağ ve Sırbistan geliyordu. İspanyol basını Mart 1876'da Karadağ Prensi ile Türk elçisi arasında bir görüşme olduğunu ve Prensin elçinin şikâyetlerine fazla cevap veremediğini belirtmiştir. Elçi, Karadağ Prensi'ne Bâbıâli'nin “Karadağ'ın Adriyatik'te bir limana sahibi olmak istediğini ve Arnavutluk'unda bunu vermeye istekli olduğunu" bildiğini söylemesi üzerine Prens halkının Osmanlı boyunduruğunu reddettiğini hangi reformlar yapılırsa yapılsın bağımsızlıklarını elde edene kadar savaşacaklarını söylemiştir. ${ }^{104}$ Presin ifade ettiği sözler Balkan milletlerinin bağımsız oluncaya kadar girişimlerinden vazgeçmeyeceklerinin açık bir beyanıdır. İlerleyen yıllarda Balkan milletlerinin bağımsızlıklarını kazanmalarının da yeterli olmadığı yaşanan gelişmelerden anlaşılmıştır.

Bosna ve Hersek'te ayaklanmanın büyüdüğü bir ortamda Osmanlı Devleti'nin eskimiş ve dağılmasının kaçınılmaz olduğunu düşünen bazı Avusturya gazeteleri, hükümetlerine Doğu konusunda Rusya ile tam bir anlaşmaya varmalarını tavsiye etmiştir. ${ }^{105} \mathrm{Bu}$ arada Sırp General

\footnotetext{
${ }^{98}$ La Epoca, 7 Ekim 1897, s. 6.

${ }^{99}$ La Epoca, 13 Eylül 1889, s. 1

${ }^{100}$ El Siglo Futuro, 4 Kasim 1895, s. 3.

${ }^{101}$ El Siglo Futuro, 14 Ekim 1884, s.3; La Epoca, 25 Kasım 1884, s.1

102 El Siglo Futuro, 8 Kasim 1884, s.2.

${ }^{103}$ El Siglo Futuro, 11 Şubat 1876, s.3.

${ }^{104}$ El Siglo Futuro, 3 Mart 1876, s.1.

${ }^{105}$ El Siglo Futuro, 28 Nisan 1876, s.4.
} 
Komarov bir İngiliz gazetesine gönderdiği mektupta Prens Milan'ın Sırpların kralı olarak ilan edilmesinin sadece Türklerin barış olarak sunduğu hakaret edici önerilere bir cevap olmadığını ve bunun aynı zamanda Sırbistan'ın Osmanlı boyunduruğundan kurtulana kadar mücadele anlamına geldiğini belirtmiştir. ${ }^{106}$ Sırp Ulusal Meclisi Prens Milan'a gönderdiği mesajında Sırpların Türk İmparatorluğu'na karşı yürüttüğü mücadelenin yaşam, özgürlük, insan hakları için verilen bir mücadele olduğunu ve bu mücadelenin bir dine ya da başka bir ulusun haklarına yönelik olamadığını iddia ederek Türk Hükümeti kana doyumsuz olmak ve masum mağdurları öldürmekle suçlamıştır. Türklerin Paris Antlaşması ile güvence altına alınan Sırpların tüm haklarını ve bağımsızlığını yok etmeye çalıştığını iddia eden Skupçina (Sırp Ulusal Meclisi) üyeleri Osmanlı boyunduruğundan kurtulana kadar sebat edeceklerini, ulusal ordunun Sırbistan kralı olarak ilan ettiği Prensi Milan'ı kral olarak kabul ettiklerini iletmişlerdir. ${ }^{107} \mathrm{Bu}$ arada İngiltere, Rusya ve Avusturya'nın gizlice desteklediği Romanya, Sırbistan, Yunanistan ve Karadağ arasında 1876 'da Türkiye ile açıkça savaşacak olan bir koalisyon kurulmuştur. ${ }^{108}$ Temmuz 1876'da Osmanlı mevzilerine saldıran Sırplar Osmanlı birlikleri karşısında tutunamamışlardır. Rusların baskısıyla Osmanlı Devleti ateşkes antlaşması imzalamak zorunda kalmıştır. Ancak iki ülke arasındaki fikir ayrılıkların artması üzerine Rus basınının çoğu Osmanlı Devleti’ne karşı Rusya'nın savaş ilan etmesini istemiştir. ${ }^{109}$

Balkanlarda yaşanan sorunlar devam ederken Rusya 1877'de Osmanlı Devleti'ne savaş ilan etmiştir. Doksanüç Harbi sırasında Rumeli'de yaşayan Hristiyanların çoğu Rusya'nın yanında yer almıştır. Savaş sonunda ağır bir yenilgi alan Osmanlı Devleti imzaladığı Berlin Antlaşması'yla Sırbistan, Karadağ ve Romanya'nın bağımsızlığını tanımak zorunda kalmıştır. ${ }^{10}$ Ayrıca Osmanlı Devleti Girit'te 1slahat yapılmasını, Bosna ve Hersek'in Avusturya tarafından işgal edilmesi kabul etmiştir. ${ }^{11}$ Aynı antlaşmayla Büyük Bulgaristan ise Bulgar Prensliği, Şarki Rumeli Vilayeti ve Makedonya olmak üzere üçe bölünmüştür. Bu durumda Balkan devletlerinin her biri nüfus yoğunluğunun kendilerinde olduğunu belirterek Makedonya üzerinde hak iddia etmeye ve yoğun bir rekabetin içine girmeye başlamışlardır. Bu rekabet hem Makedonya'da asayişi bozmuş hem de vergiler düzenli toplanamadığı için Osmanlı Devleti büyük ekonomik kayıplar yaşamıştır. ${ }^{112}$ Berlin Antlaşması'yla Şarki Rumeli Vilayeti her ne kadar Osmanlı Devleti'ne bağlı bir vilayet olarak kalmış olsa da ayrı bir anayasası vardı ve Hristiyan bir vali tarafından yönetilecekti. Buraya Aleko Paşa Osmanlı Devleti tarafından buraya vali olarak atanmıştır. Aleko Paşa'nın Bulgarlara karşı takındığ 1 ayrıcalıklı tavır ile Türk göçmenlere karşı takındığı duyarsız tavır bölgede ilk önemli problemler olarak ortaya çıkmıştır. ${ }^{113}$ Aleko Paşa'nın izlediği politikalar Osmanl1-Rus ilişkilerini de germiştir. Ocak 1883'ün başında Filibe'deki Rus Başkonsolosu ve Rumeli Genel Valisi Aleko Paşa arasında çıkan sorunlar nedeniyle, Rusya ile Türkiye arasında büyük bir ihtilaf ortaya çıkmıştır. ${ }^{114}$

Bulgar sorunu sonraki dönemlerde de zaman zaman gündeme gelmiştir. Bu sorun hakkında Bâbıâli büyük devletlerin elçilerine birer yazı göndererek Osmanlı Hükümetinin Bulgaristan sorunu hakkındaki görüşlerini iletmiş ve Türkiye'nin Bulgaristan ve Rumeli üzerindeki

\footnotetext{
${ }^{106}$ El Siglo Futuro, 28 Eylül 1876, s.3.

${ }^{107}$ El Siglo Futuro, 29 Eylül 1876, s.3.

${ }^{108}$ La Epoca, 28 Ekim 1876; El Siglo Futuro, 23 Mart 1877, s.3.

${ }^{109}$ El Siglo Futuro, 10 Kasım 1876, s.3.

110 Ali İhsan Gencer, "Berlin Antlaşması", Di̇A, İstanbul 1992, C.V, s. 517.

${ }_{111}^{111}$ Agm, s. 517.

112 Mahir Aydın, "Makedonya Meselesi ve Amerikalı Rahibenin Kaçırılması", Osmanlı Araştırmaları, C.XVIII, İstanbul1998, s.239-241.

${ }_{113}$ Mahir Aydın, "Doğu Rumeli Vilayeti”, Ed. Güler Eren, Osmanlı, Yeni Türkiye Yayınları, Ankara 1999, C.II, s.329-331.

${ }^{114}$ El Siglo Futuro, 30 Ocak 1883, s.3.
} 
egemenlik haklarının tanınması kaydıyla tüm güçlerle anlaşmaya varmak isteğini ifade etmiştir. ${ }^{115}$ Aynı günlerde İspanyol basını Bulgaristan'daki yeni rahatsızlıklardan korkan Türk Hükümetinin, Selanik ve Üsküp'te 40 bin asker toplamasını emrettiğini belirtmiş ve Kraliçe Victoria'nın oğlu Edinburgh Dükü'nün İstanbul'a gelişine ve Bulgaristan'da yapılan seçimlerin sorunlara sebep olmasına dikkat çekmiştir. ${ }^{116}$

\subsubsection{Osmanlı-Yunan Sorunu}

Yunanistan bağımsız olduktan sonra topraklarını genişletme siyaseti izleyerek Yunanlıların meskûn olduğu bütün toprakları almaya çalışmıştır. ${ }^{117}$ Büyük devletlerin desteğini almaya çalışmış ve bu yüzden sık sık Osmanlı Devleti'yle karşı karşıya gelmiştir. ${ }^{118}$ Girit'te de kendine saha açmaya çalışan Pan-Helenik Komiteler buraya silah ve mühimmat göndermeye çalışmıştır. ${ }^{119}$ Osmanlı Devleti ise 3 bin askerle adayı takviye etmeye çalışmıştır ${ }^{120}$. Yunanistan'ın bağımsızlığında büyü rolü olan Etniki Eterya Cemiyeti bu kez Epir, Makedonya ve Girit'i Yunanistan'a bağlamak için çalışmış ve Avrupa'ya kamuoyunu kendi lehine çevirmeye çalışmıştır. ${ }^{121}$

El Liberal gazetesi saltanatının başlangıcında, Türkiye'deki çok ciddi durumu düzeltmek için yönetimde büyük reformlar yapılması gereğini kabul eden II. Abdülhamid'in ülkedeki durumu ağırlaştırmaktan başka bir şeyi başaramadığını iddia etmiş̧tir. Gazete Avrupa'nın huzurunun Makedonya ve Tesalya'da tehdit altında olmasını, kan akmasını, Hristiyanların öldürülmesini Abdülhamid'in izlediği politikalara bağlamış ve Abdülhamid'i kararsızlık, zayıflık ve korkaklıkla suçlamıştır. ${ }^{122}$ Aynı gazete Abdülhamid için "yıldız delisi" tabirini de kullanmıştır. ${ }^{123}$ Gazetenin Hristiyan bakış açısıyla II. Abdülhamid'e oldukça sert eleştiri ve suçlamalar yönelttiği ve Yunanlıların bölgede işlemiş olduğu suçları görmezden geldiği görülmektedir.

Yunanistan'ın Osmanlı Devleti'ne yönelik saldırıları iki devlet arasında gerilimi Mart 1897'den sonra daha da artmıştır. ${ }^{124}$ Macaristan Temsilciler Meclisi Konsey Başkanı Girit meselesi dışında, Balkanlar'da endişe uyandıracak herhangi bir olayın olmadığını belirtmiş ve Türkiye'nin herhangi bir isyancı hareketi bastırmaya yetecek kadar güçlü olduğunu eklemiştir. Başkan, Osmanlı İmparatorluğu'nun bütünlüğünü korumaya kararlı olan büyük güçlerin ortak tavrının barışın en büyük garantisi olduğunu ve Balkan ülkeleri arasında bazı gazetelerin iddia ettiği gibi gizli bir ittifak olmadığını ileri sürmüştür. ${ }^{125}$ Ancak bu açıklamanın üzerinden bir ay geçeden Yunanlılar Alasonya'da Osmanlı sınırına saldırmıştır. Sınırda meydana gelen çatışmada 52 Rum, iki Türklerin iki ölmüş ve 12 Türk’te yaralanmıştır. ${ }^{126}$

İngiltere Dışişleri Meclis Sekreteri Curzon, Girit konusunda ülkeler arasındaki müzakerelerin devam ettiğini ve İngiliz Hükümetinin savaşın patlamasını önlemek için elinden geleni yaptığını ileri sürmüştür. Curzon, Bâbıâli'nin bir daha yaşanmaması koşuluyla bu

\footnotetext{
${ }^{115}$ El Siglo Futuro, 7 Eylül 1886, s.3.

${ }^{116}$ El Siglo Futuro, 22 Eylül 1886, s.3; La Epoca, 22 Eylül 1887.

${ }^{117}$ Enver Ziya Karal, Osmanlı Tarihi, TTK, Ankara, 1988, C. VIII, s.112.

${ }_{118}$ El Siglo Futuro, 27 Ekim 1879, s.3; 30 Ağustos 1880, s.2; 21 Aralık 1880, s. 3 ; 15 Kasım 1895, s.1.

${ }^{119}$ El Siglo Futuro, 26 Ekim 1889, s.3.

${ }^{120}$ El Siglo Futuro, 30 Mayis 1887, s.3.

${ }^{121}$ Enver Ziya Karal, Osmanlı Tarihi, TTK, Ankara, 1988, C.VIII, s.115.

${ }^{122}$ El Liberal, 23 Nisan 1897, s.1.

${ }^{123}$ El Liberal, 20 Mart 1901, s.1.

${ }^{124}$ El Siglo Futuro, 9 Mart 1897, s.1.

${ }^{125}$ El Siglo Futuro, 15 Mart 1897, s.2.

${ }^{126}$ El Siglo Futuro, 13 Nisan 1897, s.2.
} 
saldırıyı bir savaş durumu olarak görmediğini de eklemiştir. ${ }^{127} \mathrm{Bu}$ açıklamadan Osmanlı Devleti'nin mümkün olduğunca savaştan kaçınmaya çalıştı̆̆ 1 ve barışı korumaya çalıştığ anlaşılmaktadır. El Siglo Futuro gazetesi Türkler ve Yunanlılar arasında Teselya sınırındaki son çatışmalardan bir sonuç çıkmayacağına inandığını belirttikten sonra Hellen Ulusal Birliği tarafından organize edilen grupların tekrar Osmanlı topraklarına girdiğini ve Türk birliklerine saldırdığını yazmıştır. ${ }^{128}$ Yunanistan'ın Doğu Rumeli buhranından faydalanmaya çalışması, Girit'te 1896'da çıkan isyan, Yunan hükümetinin Bâbıâli'ye karşı takındığı düşmanca tavır ve Etniki Eterya'nın oluşturduğu milis kuvvetlerinin Osmanlı sınırına yönelik saldırıları üzerine Osmanlı Devleti 17 Nisan 1897'de Yunanistan'a savaş ilan etmiştir. ${ }^{129}$ Nitekim devam eden günlerde Türkler ile Yunanlılar arasındaki çatışmalar şiddetlenmiştir. Türklerin Teselya'da kayda değer avantajlar sağlamalarına rağmen Yunanlılarla yapılan savaşın istenilen şekilde ilerlememesi üzerine Edhem Paşa görevden alınmış yerine Osman Paşa atanmıştır. İspanyol gazeteleri bu değişikliği “Türk ordusu komutanı Ethem Paşa'nın yerine Osman Paşa'nın atanması Türkler arasında bomba gibi düşmüş, Osmanlı ordusunun kazanacağı ve kendi aralarında birkaç gün içinde savaşın sona ereceğine dair bahis bile" yaptıklarını yazmıştır. ${ }^{130}$ Nitekim bu atamadan kısa bir süre sonra Türklerin harekâtı sonrasında Yunanlılar Dömeke’ye çekilmek zorunda kalmıştır. ${ }^{131}$

Yunanistan'in Dömeke Meydan Muharebesi'nde yenilmesi üzerine Rusya başta olmak üzere Avrupa devletleri olaya Yunanistan lehine müdahil olmuşlardır. Rus basını ise Türkiye'nin Yunan işgalinden daha fazla korunması için Teselya sınırının yeniden çizilmesi gerektiğini ileri sürmüştür. Bâbıâli büyükelçiler tarafından önerilen sınırın düzenlenmesine karşı çıkmış ve bazı stratejik noktaların Osmanlı topraklarına dâhil edilmesini talep etmiştir. ${ }^{132}$ Ayrıca Rus Hükümeti Bâbıâli'nin talep ettiği savaş tazminatının çok yüksek bularak karşı çıkmıştır. ${ }^{133}$ Taraflar arasında İstanbul'da dört ay süren konferans sonucunda Teselya sınırındaki bazı stratejik noktalar Osmanlı'ya bırakılmış ve savaş öncesindeki mevcut duruma dönülmüştür. Böylelikle Yunanistan'a karşı kazanılan zafer karlı bir antlaşma sağlayamamakla beraber Osmanlı Devleti'nin, Osmanlı ordusunun ve II. Abdülhamid'in prestijini artırmıştır. ${ }^{134}$ Savaşta ağır yenilgi almalarına rağmen Yunan Hükümetleri ve Etniki Eterya emellerinden asla vazgeçmemişler ve her fırsattı Girit ve Makedonya'yı almak için kullanmışlardır. ${ }^{135}$

\section{4. Şark Meselesi ve II. Abdülhamid'in Denge Siyaseti}

İspanyol basınında Osmanlı Devleti ile ilgili en çok ele alınan konulardan biri Şark Meselesi'dir. Şark meselesi, emperyalist politikalar izleyen büyük devletlerin Osmanlı Devleti'nin başta Avrupa'daki kısmı olmak üzere özellikle Ortadoğu'daki ve Afrika'daki geniş topraklarının paylaşımı, devletin hükümranlık sahası üzerinde siyasî ve iktisadî tahakküm kurulması, bu arada Müslüman olmayan halkların durumlarının istismar edilerek bağımsızlık mücadelelerine destek verilmesi ve bunun için Avrupa kamuoyunun kazanılması amaciyla yoğun bir anti-Türk propagandası halinde yürütülmesi anlamında, Osmanlı gücünün XVIII. yüzyıl başından itibaren kendini hissettiren gerilemesiyle beraber gelişen kendi aralarındaki

${ }^{127}$ El Siglo Futuro, 13 Nisan 1897, s.2.

${ }^{128}$ El Siglo Futuro, 14 Nisan 1897, s.1.

${ }^{129}$ Karal, age s.113-116.

${ }^{130}$ El Siglo Futuro, 22 Nisan 1897, s.1; 24 Nisan 1897, s.1.

${ }^{131}$ El Globo, 8 Mayis 1897, s. 1.

${ }_{133}^{132}$ El Siglo Futuro, 9 Temmuz 1897, s.3.

${ }^{133}$ El Siglo Futuro, 5 Haziran 1897, s. 3.

${ }^{134}$ Karal, age, s.113-118.

${ }^{135}$ Murat Hatipoğlu, “1897 Osmanlı-Yunan Harbi ve Yunanistan'ın Makedonya Politikası (1897-1913)”, Ed. Güler Eren, Osmanlı, Yeni Türkiye Yayınları, Ankara, 1999, C.II, s.306-309.

\section{History Studies}


şiddetli rekabetin geleneksel bir tanımlamasıdır. ${ }^{136}$ "Şark Meselesi, bugün tüm Avrupa basınını meşgul eden meseledir" diyen El Siglo Futuro gazetesi Kont Andraasy'nin Paris’te bir gazetede çıkan notu ile İngiliz Bakanlar Kurulu'nun yayınladığı benzer bir notun "Osmanlı İmparatorluğu'nun ölümünü açıklayan cenaze çanı” olduğunu ileri sürmüştür. ${ }^{137}$

1878 Berlin Antlaşması'yla Osmanlı Devleti sınırları içinde kalan Hristiyanların yaşadığı bazı bölgelerde reform yapmayı kabul etmişti. ${ }^{138} \mathrm{Bu}$ durum Avrupa devletlerinin Osmanlı Devleti'nin içişlerine karışmasına zemin hazırlamıştır. Nitekim İngiliz Büyükelçisi Sir Layard, Küçük Asya'da reformların uygulanmasını isteyen bir ültimatomu Bâbıâli'ye teslim etmiştir. E1 Liberal gazetesi ültimatomun reddedilmesi durumunda, İngiltere, Avusturya ve Fransa'nın Sultan Abdülhamid'in yerine kardeşi Reşad Efendi'yi tahta çıkması için destekleyeceklerini ileri sürmüştür. Rusya'nın böyle bir krizde Abdülhamid'i destekleyeceğini yazan gazetenin henüz Abdülhamid'in tahta çıkmasının üzerinden birkaç yıl geçmiş olmasına rağmen Şehzade Mehmet Reşad'ın adını anması dikkat çekicidir. ${ }^{139}$ İngiltere Başbakanı Gladstone ise Osmanlı'nın İngiltere'nin desteğine güvenebileceğini ancak Osmanlı Devleti'nin antlaşmalara katı bir şekilde uyması gerektiğini hatırlatmıştır. ${ }^{140}$

El Siglo Futuro gazetesi Osmanlı için "ölmekte olan yaşlı adam güçler dengesi ile yaşıyor" yorumunu yapmıştır. ${ }^{141}$ Gazete "Sultan ve Büyük Gücü" başlığı ile yayınladığı yazıda Osmanlı İmparatorunun Avrupa devletlerine karşı tutumuna dikkat çekmiş ve İzmir, Selanik ve Boğazlara yönelik tehditlerin yapıldığ1 bir dönemde Osmanlıların attığ1 diplomatik adımlarından övgüyle söz etmiştir. ${ }^{142}$ La Epoca gazetesi ise "Türkiye Sultanı ve Sarayı" başlığ 1 ile yayımladığı yazı dizisinde II. Abdülhamid'in denge siyasetine atıfta bulunmuştur. Abdülhamid'in baskı ve baştan çıkarma karışımı gibi bir politikayla büyükelçilere isteklerini dayatmayı başardığını yazan gazete Abdülhamid'in İngilizlere yakın bir politika izleyerek Rusya’yı, Çanakkale Boğazı'nı Ruslara açmakla da İngiltere'yi tehdit ettiğini, Fransızlara demir yolu ve Almanlara okul açma imtiyazı verdiğini ve Avrupa devletlerini Müslüman kolonilerindeki isyanlarla tehdit ettiğini belirtmiştir. Gazete ayrıca Padişahın Almanya temsilcilerine, Almanya'nın Fransa ve Rusya tarafından eş zamanlı saldırıya uğraması durumunda, Türkiye'nin güçlü bir şekilde silahlanmış bir doğal müttefiki olacağına dair güvence verdiğini yazmıştır. ${ }^{143}$ Böylelikle II. Abdülhamid çok katmanlı ve çok yönlü bir dış politika izleyerek Osmanlı Devleti'nin yıkılmasını geciktirmiştir.

\subsubsection{Misir Sorunu}

Doğu-Batı arasında stratejik bir geçiş noktası olan Mısır'da II. Mahmud döneminde önemli sorunlar yaşanmış ve Mehmet Ali Paşa'nın isyanı başlayan mücadele ancak 1840 Londra Antlaşması'yla çözüme kavuşturulmuştur. Ancak Osmanlı Devleti'nin Misır üzerindeki hâkimiyeti sarsılmıştır. 1869'da Süveyş Kanalı'nın açılması bölgenin önemi ve İngiltere'nin bölge üzerindeki istekleri artmıştır. ${ }^{144}$ İngiltere'nin Mısır'a yönelik izlemiş olduğu politikalar Osmanlı Devleti'nin tepkisine yol açmıştır. Bâbıâli yayınladığı bildiride Mısır'ın Osmanlı İmparatorluğu'nun ayrılmaz bir parçası olduğunu, Sultanın egemen haklarının tartışılmaz olduğunu ve Mısır'da ki mevcut haklarını her ne pahasına olursa olsun korumaya kararlı

\footnotetext{
${ }^{136}$ Kemal Beydilli, “Şark Meselesi”, DİA, İstanbul, 2010, C.XXXVIII, s.353

${ }^{137}$ El Siglo Futuro, 28 Ocak 1876, s.1.

${ }^{138}$ Gencer, agm, s.517.

${ }^{139}$ El Liberal, 6 Kasım 1879, s. 1; El Siglo Futuro, 3 Kasım 1879, s.3.

${ }^{140}$ El Siglo Futuro, 5 Mayıs 1880, s.3.

${ }^{141}$ El Siglo Futuro, 19 Şubat 1880, s.2.

${ }^{142}$ El Siglo Futuro, 25 Kasim 1880, s.3.

${ }^{143}$ La Epoca, 7 Ekim 1897, s.6.

${ }^{144}$ Seyfullah Arpacı, Sultan II. Abdülhamid, Işık Yayınları, İstanbul 2005, s.67-69
} 
olduğunu söylemiştir. ${ }^{145}$ Ancak İngiltere'nin Mısır'da kendi lehine giderek daha fazla adım attığı sonraki aylarda yapılan haberlerden anlaşılmaktadır. İspanyol basını Osmanlı hükümetinin gayri resmi gazeteleri Vakit ve Hakikat'ın Avrupa barışıyla ilgili endişelerini okuyucularına iletmiştir. Türk gazeteleri sadece Mısır hakkında değil, Tunus, Bulgaristan ve Bosna hakkında da Bâbıâli'nin haklarını talep etmeye kararlı olduğunu belirtmiştir. Fransız gazeteleri de Türkiye'nin Mısır'daki haklarına atıfta bulunarak Misır'ın Tunus'la kıyaslanamayacak önemde olduğunu belirterek Padişah'ın artık harekete geçmesi gerektiğini ve İngiltere'nin Sultanın egemen haklarına saygı göstermesi gerektiği yazmıştır. ${ }^{146}$ İspanyol basını ise Müslüman dostu gibi görünseler bile İngiliz liberallerinin Osmanlı İmparatorluğu yaşadığı sürece, barışın Avrupa'da kalıcı bir şekilde kurulamayacağına ikna edildiklerini yazmıştır. ${ }^{147}$

Türkiye ile İngiltere arasında Mısır konusunda yapılan müzakerelerin tatmin edici olmadığını, Bâbıâli’nin Mısır üzerindeki egemen haklarını korumakta 1srar ettiği ve padişahın Mısır'daki otoritesini tamamen göz ardı eden İngiltere'yi protesto ettiğini İspanyol gazetelerine yansımıştır. ${ }^{148}$ İngiltere Başbakanı Gladstone Mısır meselesinde tüm büyük güçlerin dikkate alınma hakkına sahip olduğunu ve Mısır'ın Osmanlı İmparatorluğu'nun bir parçası olmasının hepsini etkilendiğini iddia etmiştir. ${ }^{149}$ El Siglo Futuro gazetesi “Türkiye'nin Kurnaz Hareketi" başlığıyla okuyucularına duyurduğu haberde Londra Konferansı sırasında Türkiye'nin izlemiş olduğu denge politikasına atıfta bulunmuştur. Gazete Osmanlı devlet adamlarının diğer Avrupa devletlerinin kıskançlıklarının İngiltere'nin Mısır'ı işgal etmesini kesin olarak önleyeceğini düşündüklerini yazmıştır. Yıldız Sarayı'nın durumu yeniden değerlendirdiği söyleyen İspanyol basını Saray'ın önce antlaşmalar tarafından tanımlanan statükoyu yeniden kurmayı, sonra da İngiliz birliklerinin Mısır'dan tahliyesini gerçekleştirmeyi amaçladığını yazmıştır. ${ }^{150}$ La Union Catolica gazetesi İngilizlerin Mısır'ın tahliyesini ve ülkenin Osmanlı İmparatorluğu'nun yüksek egemenliğine teslim edilmesini göz ardı ettiklerini belirtmiştir. Gazete Kraliçe Victoria'nın Doğu Hristiyanlarının Türkiye'de korunması için onların lehine atılması gereken siyasi ve idari reformları Sultan Abdülhamid'e yazdığını ve Hindistan'da yaşayan milyonlarca Müslümanın hakkı için de Türklerin aynı şekilde tavsiyelerde bulunacağını yazmıştır. ${ }^{151}$ Lord Salisbury ise Osmanlı İmparatorluğu'nun toprak bütünlüğünün olmadığını iddia etmiştir. ${ }^{152}$ Misır meselesi sonraki yıllarda da gündemdeki yerini korumuştur. ${ }^{153}$

\section{II. Abdülhamid'in Tahtan İndirilme Süreci, Sürgün Yılları ve Vefatı}

Rusya sıcak denizlere inmek için birçok kez Osmanlı Devleti'yle savaşmıştır. Ancak Rusya'nın izlediği bu politika Avrupa devletlerinin özelliklede İngiltere'nin menfaatleriyle çelişmekteydi ve bu durum Avrupalı devletlerin Osmanlı Devleti'nin toprak bütünlügünden yana olmalarına sağlamıştır. Rusya, Osmanlı Devleti'ni yense bile Avrupa devletlerini aşamadığında amacına ulaşamayacağını anlamış ve yönünü Uzakdoğu'ya çevirmiştir. ${ }^{154}$ Nitekim 1905 yılında Japonlara saldıran Ruslar ağır bir yenilgi almış ve yönünü tekrar Balkanlara çevirmiştir. Rusya bu kez 1908 'de Reval Görüşmeleri'nde İngilizleri Osmanlı Devleti'ni parçalamaya ikna etmiştir. İşte bu siyasi ortam içerisinde Osmanlı Devleti'nde

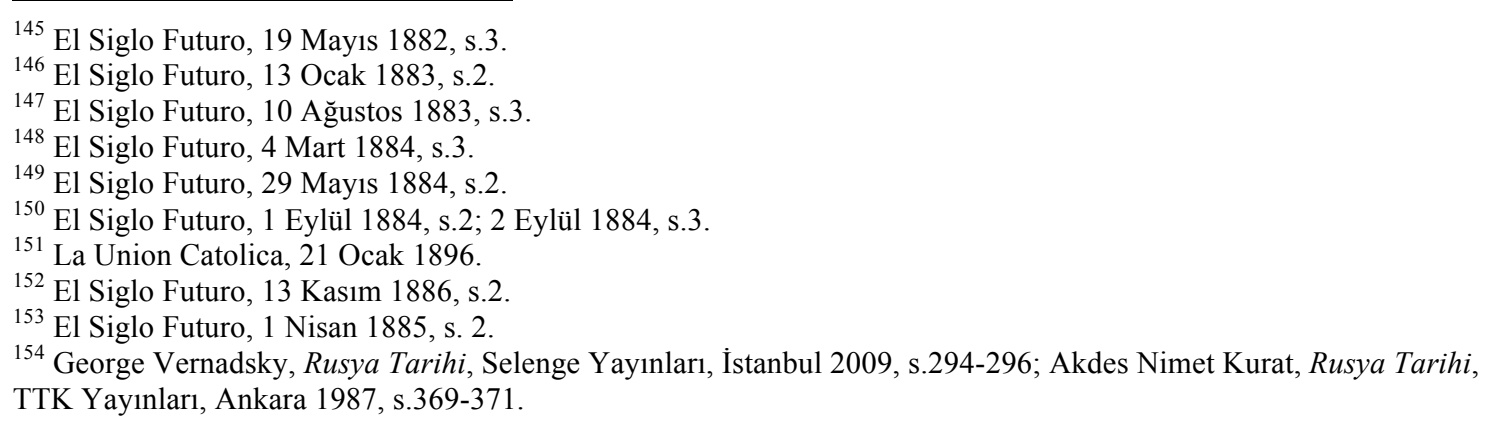


Meşrutiyet taraftarları II. Abdülhamid üzerindeki baskıyı artırmışlardır. Bunun sonucu olarak II. Abdülhamid 23 Temmuz 1908'de Meşrutiyeti yeniden ilân etmiştir.

II. Abdülhamid'in Meşrutiyeti yeniden ilan etmesi İspanyol basınında geniş yer bulmuştur. "Nadiren, bir ulusta Türkiye'de olduğu kadar beklenmedik ve hızlı bir şekilde yapılan bir siyasi rejim değişikliği vardır. Kimse İTC tarafından desteklenen hareketin Türkiye'de Anayasayı bu kadar kısa sürede getireceğini hayal edemezdi" diyen La Ilustracion Artistica bu yüzden Sultan Abdülhamid'in kısa bir süre yürürlükte kalan 1876 Anayasasını tekrar yürürlüğge koyduğunu haberini duyduğunda herkesin şaşırdığını belirtmiştir. Aynı yerde II. Abdülhamid'in bunu kendi isteğiyle yapmadığını ve Sultanın devrimcilerin dayatmalarına teslim olmaktan başka bir çaresinin olmadığını yazmıştır. Ordunun büyük bir kısmının reformistlerin taleplerini destekliğini belirten La Ilustracion Artistica askerin İstanbul'da darbe yapmaması için isteklerinin karşılanması gerektiğini ve bundan dolayı padişahın anayasayı yeniden ilan etmek zorunda kaldığını ileri sürmüştür. ${ }^{155}$

22 Temmuz gecesi Sadrazam Ferit Paşa görevden alınmış ve yerine Said Paşa atanmıştır. Aynı gece sarayda bakanların ve danışmanların katıldığı bir toplantı yapılmıştır. Uzun ve hararetli tartışmalar yapılmış ancak olumlu sonuç alınamamıştır. "Ciddi derecede hasta olmasına rağmen konseye katılmak isteyen Şeyh Ebü'l-Hüda, anayasa kelimesini telaffuz etme ve bunun tahtın kurtarılmasının tek yolu olduğunu söyleme cesaretine sahipti” diyen $L a$ Ilustracion Artistica Said Paşa ve diğerlerinin de bu teklifi desteklediklerini ancak konseyin 23 Temmuz sabahı hiçbir şeyi çözemeden dağıldığını yazmış ve "Manastırdaki büyük olayların haberi geldiğinde o gece yeniden bir araya gelindi. Savaşmak için isteksiz olan padişah Anayasayı ilan etti" demiştir. ${ }^{156}$ Abdülhamid'in samimiyetinden şüphelenmek mümkün mü? sorusuna "görünüşe göre hayır" cevabını veren gazete şu yorumu yapmıştır:

“Anayasanın ilanından iki gün sonra tabiri caizse Yıldız Köşü’nde otuz iki yıl kalmış olan Abdülhamid, kendisini dışarıda alkışlayan muazzam kalabalığa göstermek için sarayın pencerelerinden birine yaslanmak zorunda kaldl. Ve dört gün sonra, Hamidiye Camisi'ne giderken, kırk binden fazla kişi onu neşelendirdi. Selanik'te halkın sevinç gösterileri daha büyüktü... Anayasanın ilanının sonucu olarak, geniş bir af tanındı, bütün siyasi mahkûmlar serbest bırakıldl, gizli polis kapatıldl, gazete sansürü kaldırıldl ve parlamento seçimleri yapıldı. Uzun yıllardır Paris'te yaşayan Ahmet Rıza'nın başkanlı̆̆ını yaptı̆̆ İTC kazandl ". ${ }^{157}$

İkinci Meşrutiyetin ilan edilmesinin üstünden henüz bir yıl geçmemişken 13 Nisan 1909'da 31 Mart Vak'ası meydana gelmiş ve olay üzerine İTC harekete geçmiştir. İspanyol basını Jön Türklere ${ }^{158}$ bağlı binlerce askerin Selanik'ten ayrıldığını ve Çatalca'da toplandığını belirterek Jön Türklerin Sultanı anayasayı kaldırmaya çalışmakla suçlayan bir bildiri yayınladığını yazmıştır. ${ }^{159}$ Olaydan sonra İspanyol basını Reşad Efendi’nin V. Mehmet adıyla tahta çıkacağını ve Abdülhamid'in Beylerbeyi Sarayı'na kilitleneceğini yazmıştır. ${ }^{160}$ Nitekim II. Abdülhamid tahtan indirilmiş ve yerine kardeşi Mehmet Reşad geçmiştir. İspanyol basını Abdülhamid'in ölüm cezasına çarptırıldığı rivayet edildiğini yazmış ve Selanik'e sürgüne gönderilmesini ayrıntılarıyla aktarmıştır. Buna göre; Abdülhamid önce karakola götürülmüş

${ }^{155}$ La Ilustracion Artistica, 10 Ağustos 1908, s.527.

${ }^{156}$ La Ilustracion Artistica, 10 Ağustos 1908, s.527.

${ }^{157}$ La Ilustracion Artistica, 10 Ağustos 1908, s.527.

${ }^{158}$ Orijinal metinde kavram “Genç Türkler” olarak geçmektedir. Türkiye’de “Jön Türkler” kavramı kullanıldığı için metinde bu kavram tercih edilmiştir. Bkz: Sacit Kutlu, Balkanlar ve Osmanlı Devleti, İstanbul Bilgi Üniversitesi Yayınları, İstanbul 2007, s.183; Fahri Belen, 20nci Yüzyılda Osmanlı Devleti, Remzi Kitabevi, İstanbul, s.65.

${ }^{159}$ El Liberal, 13 Nisan 1909, s.1.

${ }^{160}$ El Liberal, 28 Nisan 1909, s.1. 
daha sonra o, on bir kadını ve bir oğlu beş memurunun eşlik ettiği bir vagona yetiştirilmiştir. İki memur Abdülhamid'in yanında durmuştur. Abdülhamid'i taşıyan tren saat 22'de Selanik'e ulaşmıştır. Abdülhamid tren istasyonundan Fethi Bey, bazı siviller ve otuz jandarma eşliğinde alınarak kalacağı Villa Allantina'ya (Alatini Köşkü) götürülmüştür. ${ }^{161}$

La Epoca gazetesi Selanik’te gözaltında iken Abdülhamid'in gazeteleri okuyamadığını ve meydana gelen ciddi olayları bilmediğini iddia etmiştir. ${ }^{162} \mathrm{Bu}$ arada yaşanan Balkan Savaşları'nda Osmanlı Devleti ağır bir yenilgi almıştır. La Epoca gazetesi Türk mahkûmların bu yenilgileri Abdülhamid'i tahttan indirenlerin Kur'an aleyhindeki günahların meyvesi olduğunu söylediklerini yazmıştır. ${ }^{163}$ Aynı gazete "ITC döneminde de yine Abdülhamid'in imparatorluğu döneminde olduğu gibi terör ve casusluk rejimi hüküm" sürdüğü ve yerel basının sıkı bir denetim altında olduğunu ileri sürmüştür. ${ }^{164}$ Balkan Savaşları'nda Selanik kaybedilince II. Abdülhamid İstanbul'a getirilmiş ve 1 Kasım 1912'de Beylerbeyi Sarayı'na yerleştirilmiştir.

İspanyol basınında 10 Şubat 1918'te vefat eden II. Abdülhamid'in hayatını anlatan yazılar yayımlanmıştır. La Epoca yayınladığı yazıda Abdülhamid'in oldukça liberal bir anayasa ilan ederek göreve başladığını ancak kısa sürede bu davranıştan pişmanlık duyduğunu ve Osmanlı İmparatorluğu'nun eski mutlakıyetçi uygulamalarına geri döndüğünü yazmıştır. “1897'de Yunanlılara karşı savaşta başarılı oldu; ancak Avrupa güçleri tarafından dayatılan Girit'in neredeyse bağımsızlığı, onun zafer meyvesinin tadını çıkarmasını engelledi” diyen gazete Abdülhamid'in Makedonya'daki Türk askerlerinin ve Ermenistan'daki Kürtlerin aşırıllı̆̆ını reddetmesine rağmen Hıristiyanların öldürülmesi sebebiyle kendisine Kızıl Sultan denildiğini yazmıştır. ${ }^{165}$

\section{Sonuç}

Sultan Abdülhamid'in Osmanlı Devleti'nin en buhranlı günlerini yaşandığı bir dönemde Osmanlı tahtına çıkmıştır. Tahta çıkmasına pek ihtimal verilmediği için tahta çıkıncaya kadar pek tanınan biri değildi. Bu yüzden tahta çıktığında uluslararası basının gündemini uzun süre meşgul etmiştir. İspanyol basını da Sultan Abdülhamid'e yoğun ilgi gösteren bu basın arasında yer almıştır. Birçok açıdan Sultan Abdülhamid'i okuyucularına tanıtmak isteyen İspanyol basını bu konuda yoğun çaba sarf etmiştir. II. Abdülhamid bazı açılardan İspanyol basını tarafından eleştirilmiş olsa da zeki bir insan olduğu sıklıkla vurgulanmıştır. İspanyol basını özellikle II. Abdülhamid'in Hristiyanlara karşı izlediği politikalar eleştirmiş olsa da onun büyük devletlere karşı izlemiş olduğu denge siyasetinden övgüyle bahsetmiştir.

"Altın bir kalbe sahip" olarak nitelediği II. Abdülhamid'in misafirperverliğine vurgu yapan İspanyol gazeteleri Sultanın etrafindaki insanlara güvenmekte zorlandığını ve bu yüzden ihtiyatlı davrandığını yazmıştır. İç siyasette adım atarken uluslararası dengeleri gözeten II. Abdülhamid önemli görevlere yurtsever insanları atamıştır. ${ }^{166}$ Kendisine karşı birçok komplonun kurulduğu, muhaliflerin Boğaz'ın en güzel sarayında yaşayan V. Murad'1 Abdülhamid'le savaşmak için bir bayrak olarak kullanmaya çalışmaları göz önüne alındığında II. Abdülhamid'in güvenlikle ilgili endişelerinin yersiz olmadığını anlaşılmaktadır. ${ }^{167} \mathrm{Bu}$

\footnotetext{
${ }^{161}$ El Liberal, 30 Nisan 1909, s. 1.; Ali Cevat Bey, İkinci Meşrutiyetin İlânı ve Otuzbir Mart Hâdisesi, Faik Reşit Unat (Haz.), Ankara 1985, s.74-87.

${ }_{162}$ La Epoca, 29 Ekim 1912, s.2.

${ }^{163}$ La Epoca, 7 Kasim 1912, s.1.

${ }^{164}$ La Epoca, 25 Kasim 1912, s.1.

${ }^{165}$ La Epoca, 11 Şubat 1918

${ }^{166}$ La Union, 15 Ekim 1880; La Epoca, 14 Kasım 1889, s. 2; La Iberia, 8 Aralık 1878, s. 1; El Siglo Futuro, 4 Kasım 1895, s. 3; La Dinastia, 10 Eylül 1891, s. 1.

${ }^{167}$ El Siglo Futuro, 17 Şubat 1896, s. 1; La Epoca, 2 Mart 1889, s. 3.
} 
endişelerin bir sonucu olarak II. Abdülhamid Dolmabahçe ve Çırağan Sarayı'nı terk ederek daha mütevazı olan Yıldız Sarayı'nda yaşamış ve nadiren dışarı çıkmıştır. ${ }^{168}$ Bununla birlikte Sultan Abdülhamid yabancı basını yakından takip etmiş kendisi veya ülkesi hakkında çıkan olumsuz haberlere hemen müdahale etmiştir. ${ }^{169}$

İspanyol basınında çıkan haberler II. Abdülhamid'in Sırp, Yunan, Makedon, Bulgar, Ermeni, Mısır, Tunus gibi sorunlarla uğraşırken İngiltere, Rusya, Almanya, Fransa ve Avusturya gibi ülkelerde yoğun bir şekilde mücadele etmek zorunda kaldığını göstermektedir. II. Abdülhamid'in iç siyasette de birçok sorunla uğraşmak zorunda kalmıştır. İspanyol basınına II. Abdülhamid'in büyük devletlerin hiçbirine güvenmediği ancak bu devletlerin kendi aralarındaki çekişmelerden ustaca yararlandığı da yansımıştır. II. Abdülhamid'in sadece siyasi hayatı ve devlet kişiliğiyle değil günlük hayatıyla ilgili birçok ayrıntı İspanyol basınında yer almıştır. Bu ayrıntılardan biri olarak İspanyol basını Abdülhamid'in her gün leylak, menekşe ve melisadan oluşan bir banyo yaptığını okuyucularına aktarmıştır. ${ }^{170}$

İspanyol basını sadece Osmanlı Devleti ve II. Abdülhamid'le değil saray, şehzade ve hanım sultanların yaşantılarıyla da ilgilenmiştir. İspanyol gazeteleri Sultanın kardeşi Nureddin Efendi'nin ve karısının ölüm haberlerini ve Abdülaziz'in üç kızı ile Sultan Abdülhamid'in kızının düğünlerini okuyucularına iletmiştir. ${ }^{171}$ İspanyol gazeteleri II. Abdülhamid'i ve Osmanlı Devleti'ni yakında takip etmiş ve birçok haber yapmıştır. İspanyol gazetelerinde Osmanlı Devleti'yle ilgili çıkan haberlerde Sultan, Sadrazam, Şeyhülislam gibi Türkçe bazı kavramları olduğu gibi kullanmıştır. Osmanlı Devleti’nin İspanyol basınında oldukça geniş yer bulması Osmanlı Devleti'nin zayıf olmakla birlikte büyük devlet olma vasfinı koruduğunu göstermektedir.

\section{Kaynakça}

1) Kitap ve Makaleler:

AKARLI, Engin, “II. Abdülhamid: Hayatı ve İktidar”, Ed. Güler Eren, Osmanlı, Yeni Türkiye Yayınları, Ankara 1999, C.II, s.253-266.

AKYILDIZ, Ali, "II. Abdülhamid'in Çalışma Sistemi, Yönetim Anlayışı ve Bâbıâli'yle (Hükümet) İlişskileri” Ed.Güler Eren, Osmanl, Yeni Türkiye Yayınları, Ankara 1999, C.II, s.286-297

Ali Cevat Bey, İkinci Meşrutiyetin İlânı ve Otuzbir Mart Hâdisesi, Haz. Faik Reşit Unat, Ankara 1985.

ARMAOĞLU, Fahir, 19. Yüzyıl Siyasi Tarihi, TTK Yayınları, Ankara, 1999, s.270.

ARIKAN, Muzaffer, "XIV- XVI. Asırlarda Türk-İspanyol Münasebetlerine Toplu Bir Bakış", Ankara Dil Tarih Coğrafya Fakültesi Dergisi, C. XXIII, S. 3-4, Ankara, 1965, 239256.

ARIKAN, Muzaffer, "Türk-İspanyol Münasebetleri Bakımından Aragon Kraliyet Arşivi'nin Ehemmiyeti Ve Türklerle İlgili Vesikalar" Ankara Üniversitesi Tarih Araştırmaları Dergisi, 1964, C.II, s.251-275.

ARPACI, Seyfullah, Sultan II. Abdülhamid, Işık Yayınları, İstanbul, 2005.

\footnotetext{
${ }^{168}$ La Ilustración Española y Americana, 15 Temmuz 1882, s. 14.

${ }^{169}$ El Imparcial, 9 Eylül 1887.

${ }^{170}$ El Tocador, 5 Ekim 1902.

${ }^{171}$ La Epoca, 5 Ekim 1887, s. 3; 21 Aralık 1885, s. 1; 26 Ocak 1909, s.1
} 
AYDIN, Mahir, "Doğu Rumeli Vilayeti”, Ed.Güler Eren, Osmanl, Yeni Türkiye Yayınları, Ankara 1999, C.II, s.329-334.

AYDIN, Mahir, "Makedonya Meselesi ve Amerikalı Rahibenin Kaçırılması", Osmantı Araştırmaları, C.XVIII, İstanbul 1998, s.239-247.

AYDIN, Mithat, “İstanbul Konferansı”, DİA, Ek C.1, İstanbul 2016, 673-674.

BELEN, Fahri, 20nci Yüzyllda Osmanlı Devleti, Remzi Kitabevi, İstanbul.

BEYDİLLİ, Kemal, “Şark Meselesi”, DIA İ̀stanbul 2010, C.XXXVIII, s. 352-357.

BOZARSLAN, Hamit, Türkiye Tarihi, İletişim Yayınları, İstanbul, 2015

ÇAKILCI, Diren, "Sultan II. Abdülhamid'in Hayvan Merakı: Yıldız Sarayı'nda Kuşluk-I Hümâyûn Teşkilatı", Tarih Dergisi, S.68 (2018/2), İstanbul 2018, s.57-100.

ÇETINSAYA, Gökhan; BUZPINAR, Ş. Turan, "Midhat Paşa", DİA, İstanbul 2005, C.XXX, s.7-11.

DANIŞMAN, Zuhuri, Osmanlı İmparatorluğu Tarihi, Zuhuri Danışman Yayınevi, İstanbul, 1966, C.XII.

HATIPOĞLU, Murat, “1897 Osmanl1-Yunan Harbi ve Yunanistan'ın Makedonya Politikası (1897-1913)”, Ed. Güler Eren, Osmanlı, Yeni Türkiye Yayınları, Ankara 1999, C.II, s.306-312.

HÜLAGÜ, Metin "Bir İnsan Olarak Sultan II. Abdülhamid", Devr-i Hamid Sultan II. Abdülhamid, Erciyes Üniversitesi Yayınları, C.III, s.223-242.

GENCER, Ali İhsan, "Berlin Antlaşması”, DİA, İstanbul 1992, C.V, s.516-517.

GEORGEON, Fraçois, "II. Abdülhamid”, Ed. Güler Eren, Osmanl, Yeni Türkiye Yayınları, Ankara 1999, C.II, s.266-274.

KARAL Enver Ziya, Osmanlı Tarihi, TTK, Ankara 1988, C.VIII.

KÖKSAL, Osman, "Sultan Aziz'in Avrupa Seyahati Dönüşü Münasebetiyle Yapılan Kutlamalar Ve Bir Manzum Tarihçe", Osmangazi Üniversitesi Sosyal Bilimler Dergisi, C.IV S.1, Haziran 2003, s.117-136.

KURAT, Akdes Nimet, Rusya Tarihi, TTK Yayınları, Ankara 1987.

KUTLU. Sacit, Balkanlar ve Osmanlı Devleti, İstanbul Bilgi Üniversitesi Yayınları, İstanbul 2007.

KÜÇÜK, Cevdet, “Abdülaziz”, DİA, İstanbul 1988, C.I, 179-185.

KÜÇÜK, Cevdet, “Abdülhamid II”, DİA, İstanbul 1988, C.I, s.216-224.

LEWIS, Bernard, Modern Türkiye'nin Doğuşu, TTK Yayınları, Ankara, 2000.

LEZCANO, Victor Morales, "İspanya Ve Türkiye: Birbirlerini Tanımamazlıktan Yakınlaşmaya Doğru”, OTAM Dergisi, Ankara 1991, C.II, s.218.

SHAW, Standtford J.; SHAW, Ezel Kural, Osmanlı Imparatorluğu ve Modern Türkiye, E Yayınları, İstanbul 1994.

ŞEBER, Nurdan İpek, "Namlunun Ucundaki Padişah: II. Abdülhamid'e Karşı Planlanan Suikastler", Türkiyat Mecmuası, 2012, C.XXII, S. 1, s.31-59. 
ŞEHSUVAROĞLU, Haluk Y., Sultan Aziz, TBMM Milli Saraylar Yayını, İstanbul 2011.

VERNADSKY, George, Rusya Tarihi, Selenge Yayınları, İstanbul 2009.

TURAN, Tufan, "Midhat Paşa'nın Azli ve Sürgününün İspanyol Basınındaki Yansımaları ve Paşa'nın İspanya Seyahati”, History Studies, Volume 6, Issue 4, July 2014, s.201-218.

TURAN, Tufan, "İspanyolların Gözünden Osmanlı Devleti’nde 1876 Darbesi ve Sultan II. Abdülhamid'in Tahta Çıkış Süreci”, TAD, C.38/S. 65, 2019, 279-302

YAZIKSIZ, Necip Asım, Cennet-mekân Firdevs-i Asşiyân Sultan Abdülaziz Han Hazretlerinin Avrupa Seyahatnamesi (http://isamveri.org/pdfosm/D02076/1335-1338 49-62/1335$1338 \quad 49-62$ ASIMN2.pdf)

\section{2) Süreli Yayınlar}

Crónica de Cataluña

El Dia

El Globo

El Liberal

El Imparcial

El Pabellón Nacional

El Siglo Futuro

El Tocador

La Dinastia

La Epoca

La Iberia

La Ilustracion Artistica

La Ilustración Española y Americana

La Union

La Union Catolica 


\section{Ekler:}
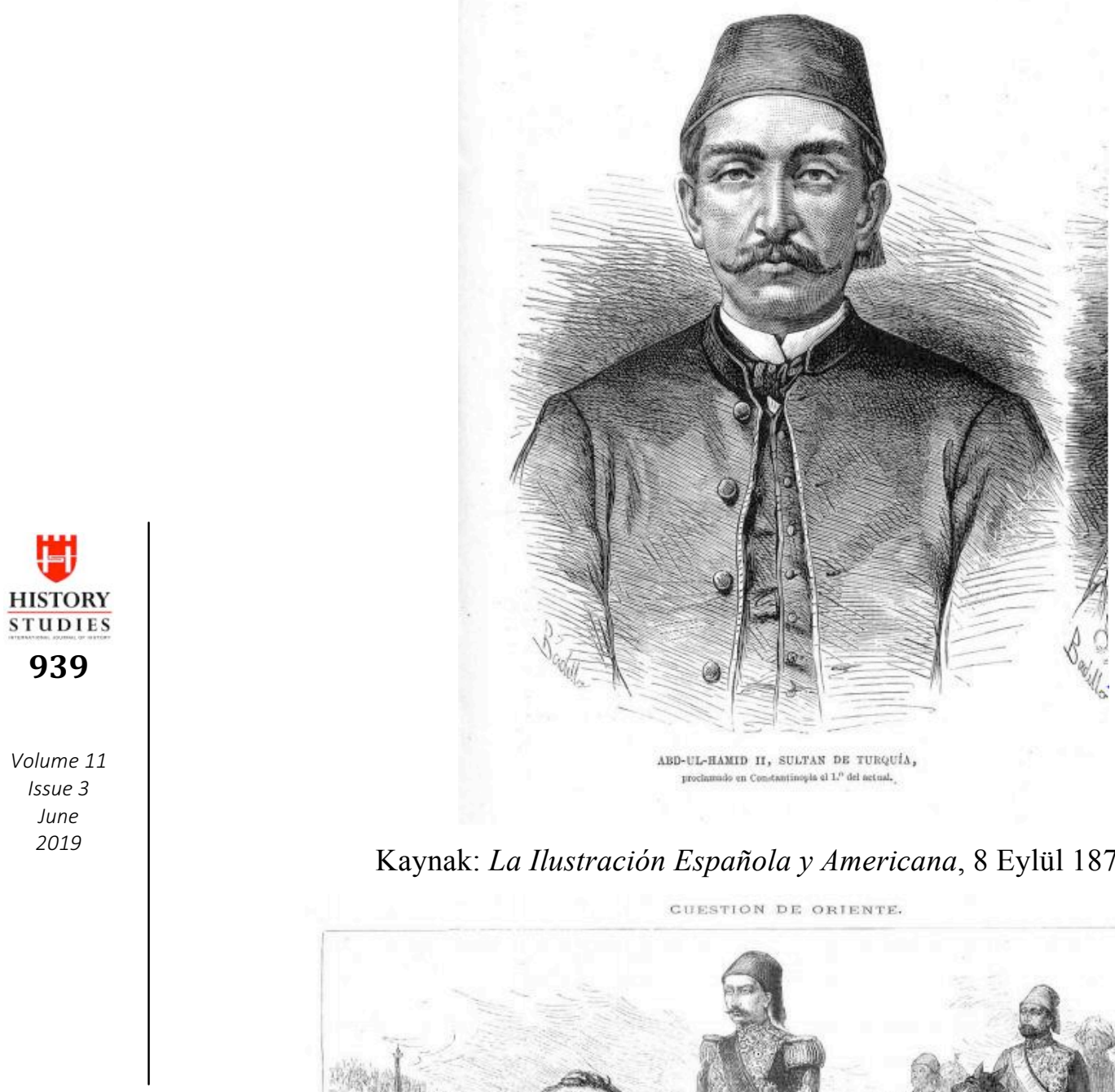

Kaynak: La Ilustración Española y Americana, 8 Eylül 1876. s.1.

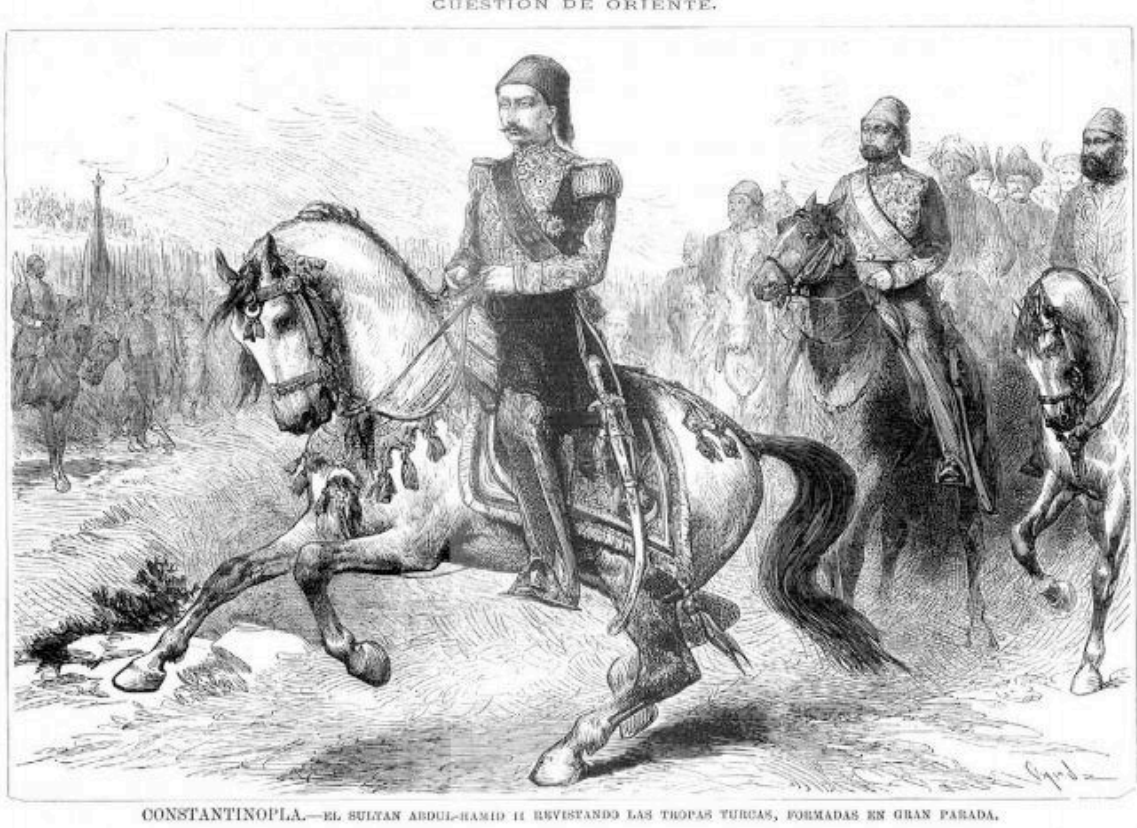

Kaynak: La Ilustración Española y Americana, 8 Şubat 1877, s.4. 


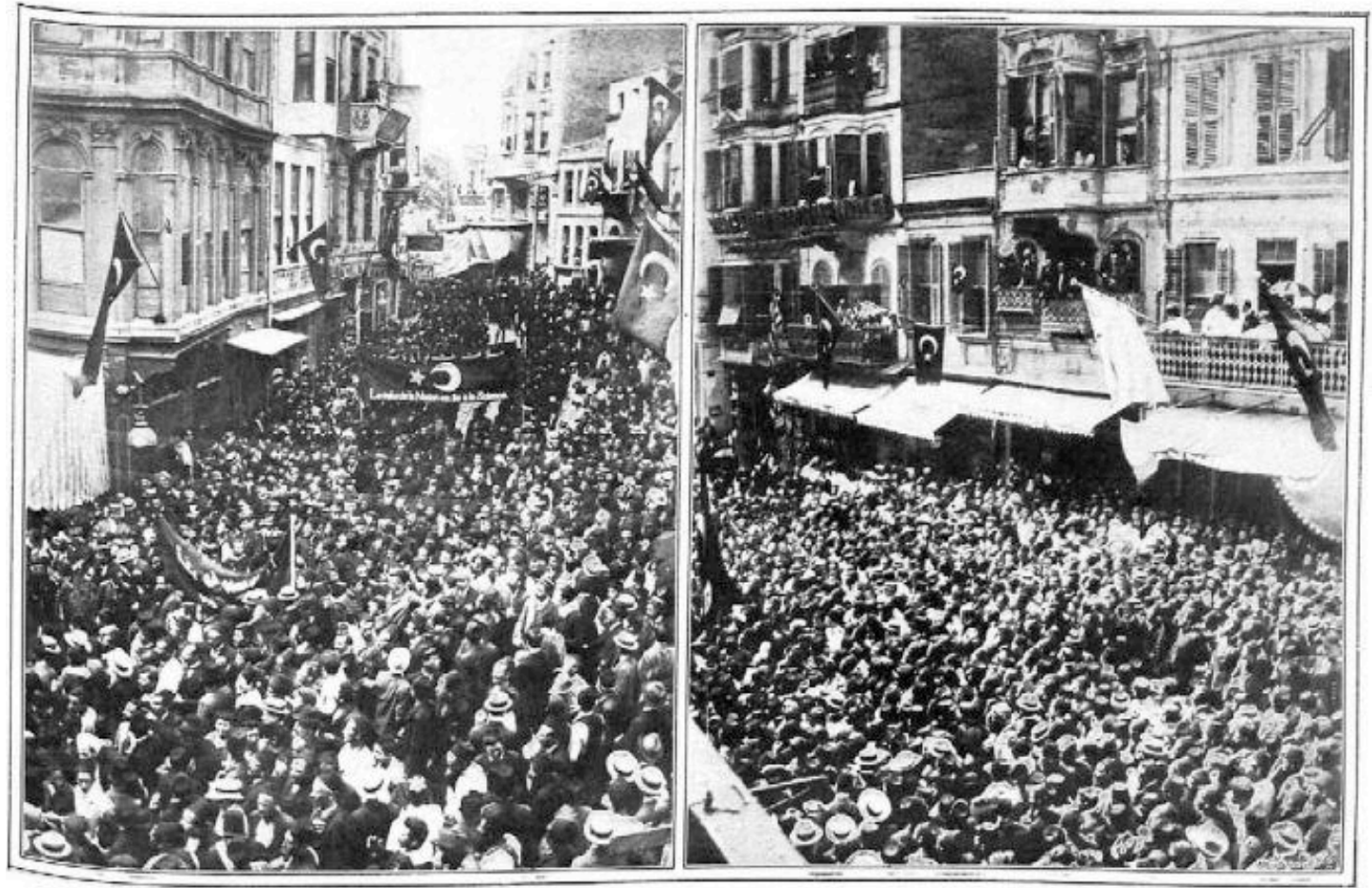

Manifestación en la Gran Via y delaate de la Prefectura, en Pera.

Vesocrallas de R, riorith

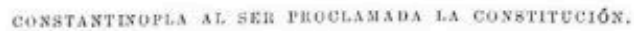

Kaynak: La Ilustración Española y Americana, 22 Ağustos 1908, s.99.

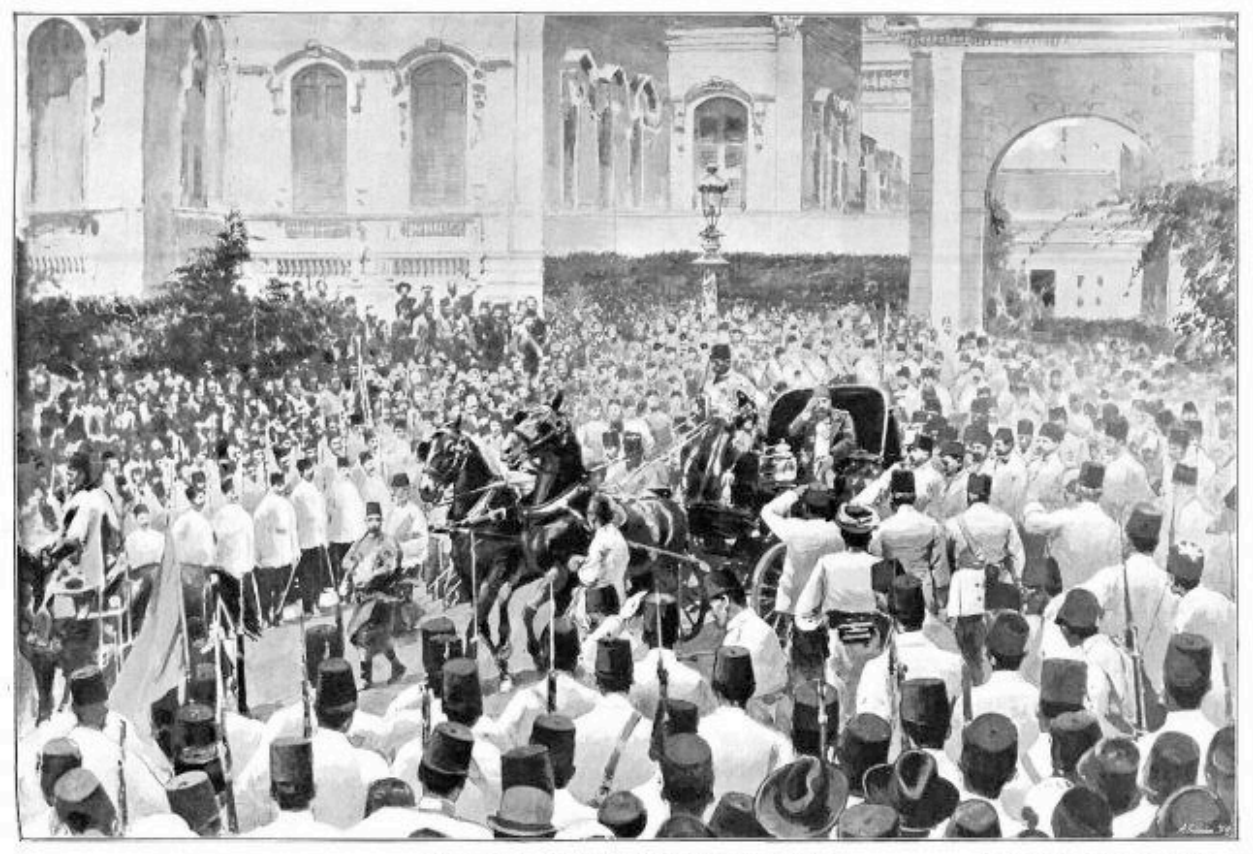

Kaynak: La Ilustración Española y Americana, 22 Ağustos 1908, s.100.
버

HISTORY

940

Volume 11

Issue 3

June

2019 


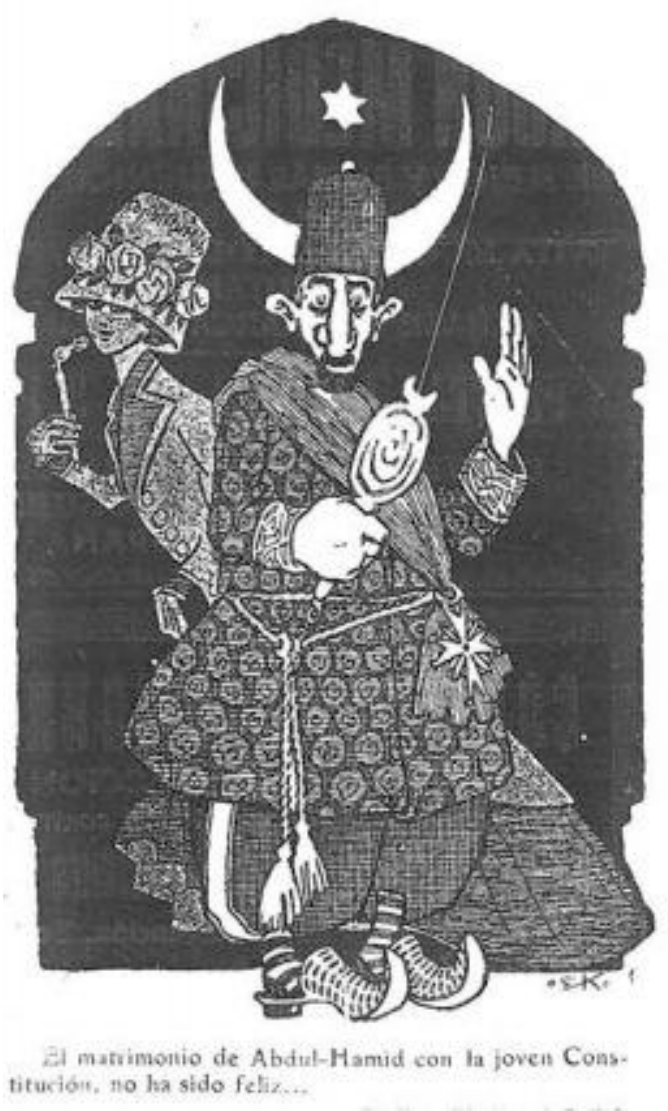

Kaynak: Gedeón, 30 Mayıs 1909, s.15. 